\title{
Lysobacter, a New Genus of Nonfruiting, Gliding Bacteria with a High Base Ratio
}

\author{
PENELOPE CHRISTENSEN AND F. D. COOK \\ Department of Microbiology, University of Alberta, Edmonton, Alberta, Canada
}

\begin{abstract}
Highly mucoid, cream, pink and yellow-brown gliding organisms having deoxyribonucleic acid guanine-plus-cytosine contents of 62 to $70.1 \mathrm{~mol} \%$ have been isolated by several workers, but since these organisms have never been observed to produce typical myxobacterial fruiting bodies, their taxonomy has been problematical. Forty-six isolates were studied in detail, among them Ensign and Wolfe's organism AL-1 and Cook's isolate 495, both of which produce important proteases, as well as Cook's culture $3 \mathrm{C}$, which elaborates the potent, widespectrum antibiotic myxin. A new genus, Lysobacter, has been established for these organisms, and four new species and one new subspecies have been named and described: L. antibioticus (type strain, ATCC 29479), L. brunescens (type strain, ATCC 29482), L. enzymogenes (type strain, ATCC 29487), L. enzymogenes subspecies cookii Christensen (type strain, ATCC 29488), and L. gummosus (type strain, ATCC 29489). The dimensions of the thin, gliding, flexing cells of Lysobacter are 0.3 to 0.5 by 1.0 to 15.0 (sometimes up to 70 ) $\mu \mathrm{m}$. These soil and water organisms all degrade chitin, two degrade alginate, three degrade pectate, three degrade carboxymethylcellulose, and one degrades starch, but none decomposes filter paper or agar. They are strongly proteolytic and characteristically lyse a variety of microorganisms such as gram-negative, gram-positive (including actinomycetes), and blue-green bacteria, fungi, and green algae, as well as nematodes. The genus has been placed in a new family, Lysobacteraceae, within a new order, Lysobacterales.
\end{abstract}

The existence of albuminous, nonfruiting, gliding bacteria, many of which lyse other microorganisms and have high guanine-plus-cytosine $(\mathrm{G}+\mathrm{C})$ contents in their deoxyribonucleic acids (DNAs) has been noted by various authors $(9,12,14,18,23,27,28,30,34-36$; E. J. Napier, British Patent 1,048,887, 1966). Some of these organisms are known to produce important proteases $(1,10,12-17$; L. Y. Huang and J. C. Ensign, Bacteriol. Proc., P22, p. 127, 1971) and polysaccharases (15), one elaborates a potent, wide-spectrum antibiotic $(4,19-21,27 ; \mathrm{F}$. D. Cook, O. E. Edward, D. C. Gillespie, and E. R. Peterson, U. S. Patent 3,609,153, 1971), and another produces an extremely viscid gum. Several of them were tentatively assigned to the formerly recognized genus Sorangium (14, 27, 34, $38-42)$, to Cytophaga $(12,25,26,35$; Napier, British Patent 1,048,887, 1966), or to Flexibacter (34), but the majority have been referred to as "unidentified myxobacters."

In a paper presented at the 23 rd Annual Meeting of the Canadian Society of Microbiologists in Edmonton, Alberta, in 1973, Christensen and Cook introduced the new genus Lysobacter. Three species and one subspecies were described, and the genus was at that time placed within the order Myxobacterales. However, presentation of new names at meetings does not constitute effective publication, and thus the purpose of the present report is to effect the valid publication of the names of these and other taxa and to discuss the taxonomic relationships of these taxa. The names proposed in this paper are Lysobacter gen. nov., $L$. antibioticus sp. nov., $L$. brunescens sp. nov., L. enzymogenes $\mathrm{sp}$. nov., $L$. enzymogenes subsp. cookii sp. nov., $L$. gummosus sp. nov., Lysobacteraceae fam. nov., and Lysobacterales ord. nov.

\section{MATERIALS AND METHODS}

Bacterial strains. Dilutions were prepared from soils enriched with chitin, ground mushrooms, or $\mathrm{Ar}$ throbacter cells for at least 1 month and then spread on yeast cell agar (32), which consists of $0.5 \%$ bakers' yeast in a $1.5 \%$ agar medium. The number of colonies capable of lysing autoclaved yeast cells (Fig. 1) increased dramatically with these enrichment procedures (Fig. 2). The "predators" belonged mainly to one of two groups-those that produced cream-colored colonies ("495 types," now L. enzymogenes) or those that produced pink-colored colonies ("3C types," now $L$. antibioticus). Thirty of the cream organisms and 24 of the pink ones were isolated and purified. Two other cream strains were acquired. ATCC 27796 was kindly donated by R. S. Wolfe, and the American Type Culture Collection supplied ATCC 21123. In all, 


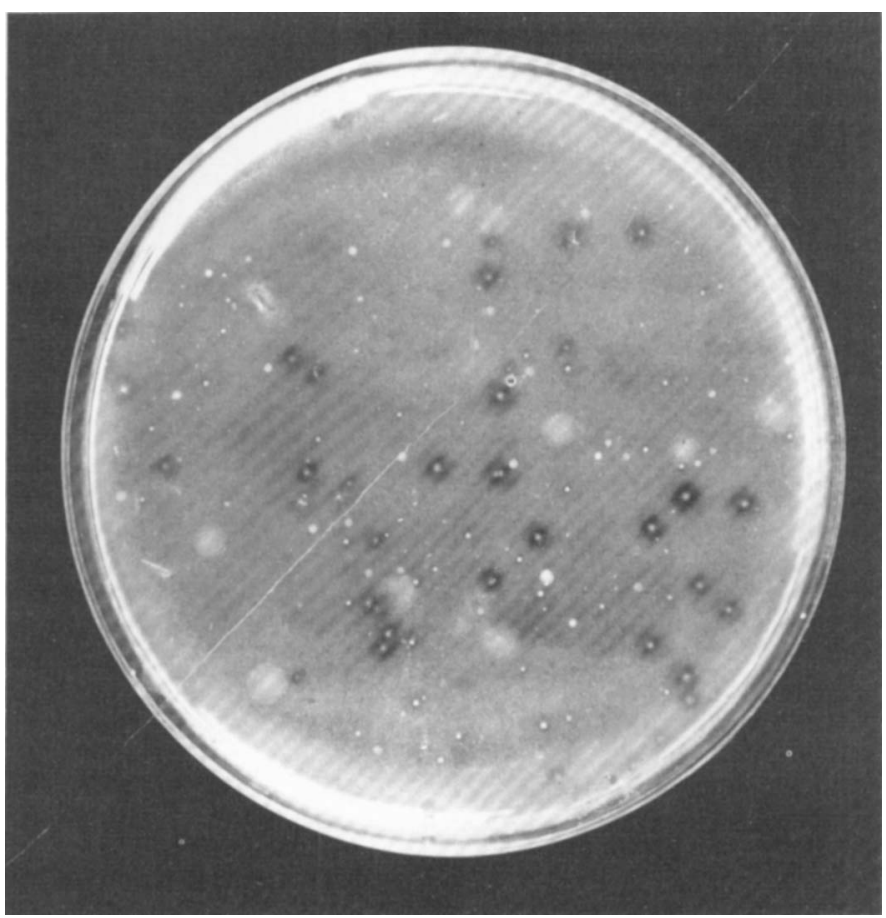

FIG. 1. One-tenth milliliter of a soil dilution, spread on a yeast cell agar plate, after 3 days of incubation at $26^{\circ} \mathrm{C}$. Note the lytic zones around some of the colonies.

19 strains of the cream type and 16 of the pink type, together with one unusual, gummy, off-white isolate, were used in the present study. These and the other strains used here are listed, together with their sources, in Table 1. Most of the cream organisms had at least two cultural variants-a dirty-white mucoid colony and a yellowish nonmucoid one-which were tested separately in the physiological and biochemical tests.

Water samples were also plated on yeast cell agar, and these yielded several lytic colonies. Ten yellowbrown isolates were purified, and all of these were used in the present study (see Table 1).

Media. The media used for growing the organisms were plate count agar (PCA; Difco), Cook's cytophaga agar (CCA; 8), and skim acetate agar (SAA) or broth (8); incubation was at $25^{\circ} \mathrm{C}$ unless otherwise noted.

Methods. The methods used in this study were the same as those published in a previous study (7) with the following additions.

Induction of fruiting. Fruiting was induced by inoculating onto sterile rabbit pellets in water agar (32) and by the glycerol technique (11).

Lipolysis. Separately autoclaved solutions of Tween $20,40,60$, and 80 were added to four different batches of basal agar (1.0\% peptone- $0.02 \% \mathrm{CaCl}_{2}-1.5 \%$ agar [ $\mathrm{pH} 7.2$ to 7.4$]$ ), to achieve a final concentration of $1 \%(\mathrm{vol} / \mathrm{vol})$, just prior to pouring the plates (31). Two-day-old plates were inoculated with the test organisms, and, after 5 days, observation with the naked eye was made to see whether crystals of the calcium soaps had been formed as a result of lipolytic action.
Indole, methyl red, Voges-Proskauer, citrate. The method used for detecting indole production was reported previously (7). The medium used for the methyl red (MR) and Voges-Proskauer (VP) tests contained $0.5 \%$ peptone, $0.5 \%$ glucose, and $0.5 \%$ $\mathrm{K}_{2} \mathrm{HPO}_{4}$. Simmons citrate agar (3) was used to determine the utilization of citrate as a sole carbon source. The VP test was read after 2 days, and the MR and citrate tests were read after 4 days (3).

Lactose plates. Organisms were streaked on MacConkey agar (Difco) and on eosin-methylene blue agar (Difco), and the color of any colonies that grew was noted at 2 days.

$\mathrm{G}+\mathrm{C}$ content of the DNA. For determining the $\mathrm{G}+\mathrm{C}$ content of DNA, the methods of Marmur and Doty were followed (22).

\section{RESULTS}

(Note: The organisms forming the two colony types of $L$. enzymogenes [see Tables 3 to 5] behaved identically in all physiological and biochemical tests; therefore they are not recorded separately in the other tables.)

Cell morphology. The 46 isolates were gramnegative rods or filaments (Table 2) which were nonmotile by means of flagella but which glided along solid/liquid interfaces. All except UASM 66, UASM Q9, and UASM 402 showed flexing movements in liquid media. Flexing and gliding were more readily observed with longer cells. 


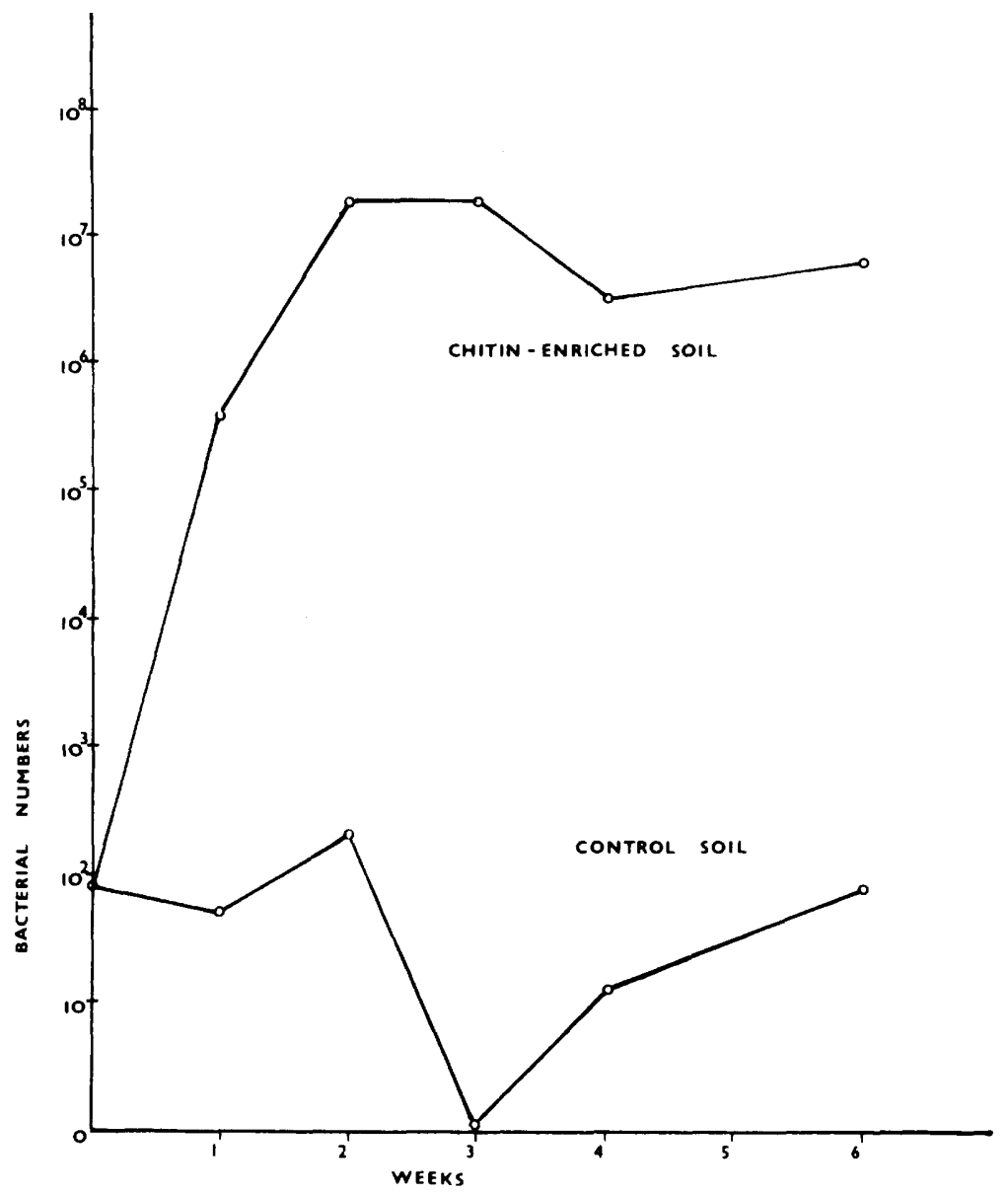

FIG. 2. Numbers of bacteria lysing autoclaved yeast cells. One set of numbers is from untreated (control) soil at 25\% moisture, the other set is from the same soil which had been enriched with chitin.

Cultural characteristics. Liquid cultures of all the strains except UASM Q9 showed a characteristic silkiness when gently tapped. This silkiness also appeared to be associated with the length of the cells, for it was less pronounced in strains with shorter cells. Liquid cultures of all four species were somewhat viscous, and L. gum mosus was so much so that a 2-day-old tube culture could be inverted with no spillage.

Likewise, all four species were mucilaginous on agar media. The rubbery colonies of $L$. gummosus were particularly difficult to handle. All strains except those of $L$. gummosus produced brown, water-soluble pigments in broth and on agar media, and this pigment production was more marked the older the culture became. The colors of the colonies were distinctive: $L$. gummosus had off-white-colored colonies, L. enzymogenes had cream-colored colonies which became brown, the yellow colonies of $L$. brunes- cens quickly became deep chocolate brown, and the pink colonies of $L$. antibioticus became reddish brown. Deep reddish-brown crystals developed within the slime of several strains of $L$. antibioticus, and these were identified as crystals of the antibiotic myxin in strain UASM $3 \mathrm{C}$ (27; Cook et al., U. S. Patent 3,609,153, 28 September, 1971). The identity of the remaining pigments is under investigation in $\mathrm{H}$. Reichenbach's laboratory, Braunschweig-Stöckheim, Federal Republic of Germany.

Colonies of $L$. brunescens spread in the typical "cytophaga" fashion, but those of $L$. antibioticus and $L$. enzymogenes were more mucoid, and we believe that this concealed the typical spreading. However, all strains of the latter two species were observed to produce a thin advancing fringe of cells at the edge of the colony. $L$. gummosus was never observed to spread, and this seemed to be associated with both the 
TABLE 1. Origins and designations of strains used in this study ${ }^{a}$

\begin{tabular}{|c|c|c|}
\hline Organism & Strain designation & Source \\
\hline Actinomycete & UASM 4432 & F. D. Cook (soil) \\
\hline Actinomycete & UASM 4441 & F. D. Cook (soil) \\
\hline Arthrobacter sp. & UASM 4165 & $\begin{array}{l}\text { F. D. Cook } \leftarrow \text { Prairie Regional Lab; Sas- } \\
\text { katchewan }\end{array}$ \\
\hline Bacillus subtilis & UASM 4611 & $\begin{array}{l}\text { F. D. Cook } \leftarrow \text { Prairie Regional Lab; Sas } \\
\text { katchewan }\end{array}$ \\
\hline Chlorella sp. & & Dept. of Botany, U. of Alberta \\
\hline Cytophaga hutchinsonii & NCIB 10782 & NCIB $\leftarrow \mathbf{N}$. Palleroni \\
\hline C. hutchinsonii & Stanier 6 & R. Y. Stanier \\
\hline Escherichia coli & UASM PC20 & $\begin{array}{l}\text { P. Christensen (creek water, Edmonton, } \\
\text { Alberta) }\end{array}$ \\
\hline Lysobacter antibioticus ${ }^{b}$ & $\operatorname{UASM} 3 \mathrm{C}^{r, d}(=\operatorname{ATCC} 29479)$ & Soil, CEF, Ottawa, Ontario \\
\hline L. antibioticus & UASM 66 & Variant from UASM $3 \mathrm{C}$ culture \\
\hline L. antibioticus & UASM L17 (= ATCC 29480$)$ & Soil, CEF, Ottawa, Ontario \\
\hline L. antibioticus & UASM Q9 & Soil, Edmonton, Alberta \\
\hline L. antibioticus & UASM Q15 & Soil, Edmonton, Alberta \\
\hline L. antibioticus & UASM 4045 (= ATCC 29481$)$ & Soil, CEF, Ottawa, Ontario \\
\hline L. antibioticus & UASM 4169 & Soil, Looma, Alberta \\
\hline L. antibioticus & UASM 4551 & Soil, Carmangay, Alberta \\
\hline L. antibioticus & UASM 4572 & Soil, Sylvan Lake, Alberta \\
\hline L. antibioticus & UASM 4574 & Soil, near Sylvan Lake, Alberta \\
\hline L. antibioticus & UASM 4578 & Soil, near Sylvan Lake, Alberta \\
\hline L. antibioticus & UASM 4593 & Soil, Edmonton, Alberta \\
\hline L. antibioticus & UASM 4598 & Soil, Ellerslie, Alberta \\
\hline L. antibioticus & UASM 8I & Soil, CEF, Ottawa, Ontario \\
\hline L. antibioticus & UASM 10I & Soil, CEF, Ottawa, Ontario \\
\hline L. antibioticus & UASM $12 \mathrm{I}$ & Soil, CEF, Ottawa, Ontario \\
\hline L. brunescens & UASM D ${ }^{d}(=$ ATCC 29482$)$ & Lake A water, Martin House, NWT \\
\hline L. brunescens & UASM $2(=$ ATCC 29483$)$ & Lake B water, Martin House, NWT \\
\hline L. brunescens & UASM 6 (= ATCC 29484) & Lake C water, Martin House, NWT \\
\hline L. brunescens & UASM 4541 & Slough water, Alberta \\
\hline L. brunescens & UASM CB1 & $\begin{array}{l}\text { N. Saskatchewan River, Edmonton, Al- } \\
\text { berta }\end{array}$ \\
\hline L. brunescens & UASM CB2 & $\begin{array}{l}\text { N. Saskatchewan River, Edmonton, Al- } \\
\text { berta }\end{array}$ \\
\hline L. brunescens & UASM CB4 & Fallis Creek, Alberta \\
\hline L. brunescens & UASM CB5 & Fallis Creek, Alberta \\
\hline L. brunescens & UASM CB6 & Burma Creek, Saskatchewan \\
\hline L. brunescens & UASM CB7 & Burma Creek, Saskatchewan \\
\hline L. enzymogenes $f$ & UASM $495^{r, d}(=\operatorname{ATCC} 29487)$ & Soil, CEF, Ottawa, Ontario \\
\hline L. enzymogenes & UASM AL-1 $(=$ ATCC 27796$)$ & Soil, R. S. Wolfe, Illinois \\
\hline L. enzymogenes & ATCC $21123^{\circ}$ & $\begin{array}{l}\text { ATCC } \leftarrow \text { Kyowa Fermentation Indus- } \\
\text { tries Co., Japan }\end{array}$ \\
\hline L. enzymogenes & $\begin{array}{l}\text { UASM } 18 L^{c}(=\text { ATCC } 29485 / \\
\text { (n) }\end{array}$ & Soil, CEF, Ottawa, Ontario \\
\hline L. enzymogenes & UASM 4553 & Soil, Carmangay, Alberta \\
\hline L. enzymogenes & UASM 4554 & Soil, Angus Ridge, Alberta \\
\hline L. enzymogenes & UASM 4555 & Soil, Malmo, Alberta \\
\hline L. enzymogenes & UASM 4556 & Soil, Vegreville, Alberta \\
\hline L. enzymogenes & UASM 4557 & Soil, Breton, Alberta \\
\hline L. enzymogenes & UASM 4558 & Soil, Peace River, Alberta \\
\hline L. enzymogenes & UASM 4559 & Soil, Lac la Biche, Alberta \\
\hline L. enzymogenes & UASM 4560 & Soil, Lloydminster, Alberta \\
\hline L. enzymogenes & UASM 4561 & Soil, Olds, Alberta \\
\hline L. enzymogenes & UASM 4562 & Soil, Vermilion, Alberta \\
\hline L. enzymogenes & UASM 4563 & Soil, Alberta \\
\hline L. enzymogenes & UASM 4564 & Soil, Alberta \\
\hline L. enzymogenes & UASM 4565 & Soil, Alberta \\
\hline L. enzymogenes & UASM Q1 & Soil, Edmonton, Alberta \\
\hline $\begin{array}{l}\text { L. enzymogenes } \\
\text { subsp. cookii }\end{array}$ & UASM $13 B^{d}(=$ ATCC 29488) & Soil, CEF, Ottawa, Ontario \\
\hline
\end{tabular}


TABLE 1-Continued

\begin{tabular}{|c|c|c|}
\hline Organism & Strain designation & Source \\
\hline L. gummosus & UASM $402^{d}(=$ ATCC 29489$)$ & Soil, CEF, Ottawa, Ontario \\
\hline Myxococcus sp. & UASM K54 & F. D. Cook (soil) \\
\hline Penicillium notatum & & N. Colotelo, Edmonton \\
\hline Pseudomonas aeruginosa & ATCC 9027 & ATCC $\leftarrow$ C. P. Hegarty (ear infection) \\
\hline Rhizopus sp. & & N. Colotelo, Edmonton \\
\hline Sclerotinia sclerotiorum & & N. Colotelo, Edmonton \\
\hline Serratia marcescens & & $\begin{array}{l}\text { Provincial Laboratory of Public Health, } \\
\text { Edmonton }\end{array}$ \\
\hline $\begin{array}{l}\text { Yeast (probably Saccharomyces } \\
\text { cerevisiae) }\end{array}$ & & $\begin{array}{l}\text { Fleischmann's fast-rising active dry } \\
\text { yeast, Standard Brands, Ltd. Montreal }\end{array}$ \\
\hline
\end{tabular}

"Abbreviations: ATCC, American Type Culture Collection, Rockville, Md. 20852; CEF, Central Experimental Farm; NWT, Northwest Territories; UASM, University of Alberta Soil Microbiology Lab., Edmonton, Alberta, Canada.

${ }^{b}$ All Lysobacter strains were isolated by F. D. Cook, and within each species all strains except one are from different soil or water samples; none are known to be siblings.

${ }^{c}$ Formerly placed in the genus Sorangium $(14,27,38-42)$.

'Type strain.

' Listed as Cytophaga johnsonae in ATCC catalogue.

${ }^{f}$ Type species of the genus.

shorter cells and the large amount of gum produced on every medium on which it was grown (Tables 3 to 5 ).

Fruiting bodies characteristic of members of the order Myxobacterales were not observed when these strains were inoculated on dung pellets, and microcyst production by these strains was not induced by the glycerol method.

Physiology. The physiological data on the strains are presented in Tables 6 to 8 . The temperatures for optimum growth of these organisms were relatively high $\left(25\right.$ to $\left.40^{\circ} \mathrm{C}\right)$ for soil and water organisms.

All strains except UASM AL-1 utilized ammonia, all except UASM CB1 and UASM CB2 utilized asparaginate, and all utilized glutamate and nitrate as $\mathbf{N}$ sources. The use of urea was restricted to the single strain of L. gummosus and to UASM 3C, ATCC 21123, UASM 18L, and UASM 13B. In general, the addition of yeast extract to the salts-glucose-nitrate agar, or to the chitin medium, stimulated growth.

Members of the genus Lysobacter lysed both gram-negative and gram-positive bacteria (including actinomycetes), filamentous fungi, a yeast, and an alga (Table 8). Lysobacters did not attack gram-negative as well as they did grampositive bacteria. It should be noted that lysobacters are themselves gram negative, and this may be a self-protective feature.

Biochemical reactions. The biochemical reactions of the strains are presented in Tables 9 and 10. All strains degraded chitin and all except the strains of $L$. brunescens degraded carboxy. methyl-cellulose (CMC). None of the sträins degraded filter paper or agar in tubes. Lysobacters were highly proteolytic; all strains liquefied gelatin, grew and produced $\mathrm{NH}_{3}$ in both casein and salts-Casitone broths, and grew well on tryptone agar. All strains produced catalase, oxidase (L. gummosus UASM 402 untestable), and phosphatase and gave negative results for the indole, MR, and VP tests. Citrate was used as a sole carbon source by all strains of Lysobacter except those of $L$. brunescens. (Strains UASM 4553-4565 inclusive were not tested for MR, VP, or citrate.)

According to our determinations, the $\mathrm{G}+\mathrm{C}$ content of the DNA of the lysobacters ranged from 65.4 to $70.1 \mathrm{~mol} \%$ (Table 11).

\section{DISCUSSION}

As non-photosynthetic, gliding bacteria, the organisms under study fell within the confines of part 2 of the 8th edition of Bergey's Manual (5), which contains two orders-Myxobacterales and Cytophagales. Lysobacter shows certain similarities to the Myxobacterales, notably in its ability to lyse procaryotic and eucaryotic microbes and its high DNA base ratio (65 to 70 $\mathrm{mol} \% \mathrm{G}+\mathrm{C}$ for Lysobacter, 67 to $71 \mathrm{~mol} \% \mathrm{G}+\mathrm{C}$ for the Myxobacterales). However, the myxobacteria are strict aerobes whereas lysobacters are not; some myxobacteria but none of the lysobacters degrade filter-paper cellulose; and, most important of all, lysobacters do not form fruiting bodies or microcysts of any kind. The possibility has been raised that these organisms are myxobacters that have lost the ability to fruit. We reject this possibility because we have observed 67 freshly isolated strains, and none has ever been seen to fruit during our use of appropriate techniques. Clearly Lysobacter does not belong in the order Myxobacterales. 
TABLE 2. Cell dimensions of Lysobacter strains

\begin{tabular}{|c|c|c|}
\hline Strain & $\begin{array}{c}\text { Length } \\
(\mu \mathrm{m})\end{array}$ & $\begin{array}{l}\text { Width } \\
(\mu \mathrm{m})\end{array}$ \\
\hline \multicolumn{3}{|l|}{ L. antibioticus } \\
\hline UASM 3C (ATCC 29479) & 6.5 & 0.4 \\
\hline UASM 66 & 40 & 0.4 \\
\hline UASM L17 (ATCC 29480) & 9 & 0.4 \\
\hline UASM Q9 & 6.5 & 0.4 \\
\hline UASM Q15 & 22 & 0.4 \\
\hline UASM 4045 (ATCC 29481) & 23 & 0.4 \\
\hline UASM 4169 & 16 & 0.4 \\
\hline UASM 4551 & 21 & 0.4 \\
\hline UASM 4572 & 4 & 0.4 \\
\hline UASM 4574 & 35 & 0.4 \\
\hline UASM 4578 & 40 & 0.4 \\
\hline UASM 4593 & 19 & 0.4 \\
\hline UASM 4598 & 22 & 0.4 \\
\hline UASM 8I & 6 & 0.4 \\
\hline UASM 10I & 38 & 0.4 \\
\hline UASM 12I & 37 & 0.4 \\
\hline \multicolumn{3}{|l|}{ L. brunescens } \\
\hline UASM D (ATCC 29482) & 11 & $0.3-0.5$ \\
\hline UASM 2 (ATCC 29483) & 35 & $0.3-0.4$ \\
\hline UASM 6 (ATCC 29484) & 15 & $0.2-0.5$ \\
\hline UASM 4541 & 70 & $0.3-0.5$ \\
\hline UASM CB1 & 24 & $0.3-0.5$ \\
\hline UASM CB2 & 7 & $0.4-0.5$ \\
\hline UASM CB4 & 12 & $0.3-0.5$ \\
\hline UASM CB5 & 13 & $0.4-0.5$ \\
\hline UASM CB6 & 25 & $0.4-0.5$ \\
\hline UASM CB7 & 15 & $0.4-0.5$ \\
\hline \multicolumn{3}{|l|}{ L. enzymogenes } \\
\hline UASM 495 (ATCC 29487) & 38 & 0.5 \\
\hline UASM AL-1 (ATCC 27796) & 27 & $0.3-0.4$ \\
\hline ATCC 21123 & 37 & 0.4 \\
\hline ATCC 18L (ATCC $29485 / 6$ ) & 50 & 0.4 \\
\hline UASM 4553 & 4 & $0.4-0.5$ \\
\hline UASM 4554 & 5 & 0.5 \\
\hline UASM 4555 & 6 & $0.4-0.5$ \\
\hline UASM 4556 & 5 & 0.4 \\
\hline UASM 4557 & 5 & $0.3-0.5$ \\
\hline UASM 4558 & 6 & 0.4 \\
\hline UASM 4559 & 6 & 0.4 \\
\hline UASM 4560 & 7 & 0.4 \\
\hline UASM 4561 & 8 & $0.3-0.4$ \\
\hline UASM 4562 & 7 & 0.4 \\
\hline UASM 4563 & 5 & $0.4-0.5$ \\
\hline UASM 4564 & 6 & 0.3 \\
\hline UASM 4565 & 11 & 0.4 \\
\hline UASM Q1 & 41 & 0.4 \\
\hline $\begin{array}{c}\text { enzymogenes subsp. cookii, } \\
\text { UASM 13B (ATCC 29488) }\end{array}$ & 37 & 0.5 \\
\hline $\begin{array}{l}\text { L. gummosus UASM } 402 \text { (ATCC } \\
29489 \text { ) }\end{array}$ & 2 & 0.4 \\
\hline
\end{tabular}

However, does it belong in the order Cytophagales? The $\mathrm{G}+\mathrm{C}$ content of Lysobacter DNA (65 to $70 \mathrm{~mol} \%$ ) is quite different from that of the Cytophagales (31 to $53 \mathrm{~mol} \%$ ). The wide range in $\mathrm{G}+\mathrm{C}$ content as well as the morphological and biochemical characteristics of members of this order indicate that it is too heterogeneous and that it will undoubtedly be divided into more discrete units after urgently needed studies are undertaken.

We shall, therefore, not add to the heterogeneity within the order Cytophagales but instead propose that the genus Lysobacter be placed within a new family, Lysobacteraceae, within a new order, Lysobacterales, to be placed in part 2 of Bergey's Manual.

Lysobacterales ord. nov. (Lys.o.bac.te.ra'les. M.L. masc.n. Lysobacter name of the type genus of the order; -ales ending to denote an order; M.L. fem.pl.n. Lysobacterales the Lysobacter order.)

Gram-negative, rod-shaped cells which may become quite long (up to $70 \mu \mathrm{m}$ ) and which are motile by means of gliding. Fruiting bodies are not produced. The DNA base ratio ranges from 65 to $70 \mathrm{~mol} \% \mathrm{G}+\mathrm{C}$.

Lysobacteraceae fam. nov. (Lys.o.bac.te.ra'ce.ae. M.L. masc.n. Lysobacter type genus of the family; -aceae ending to denote a family; M.L. fem.pl.n. Lysobacteraceae the Lysobacter family.)

Description as for the order.

Lysobacter gen. nov. (Lys.o.bac'ter. Gr. adj. lysis loosing; M.L. n. bacter masc. equivalent of Gr. neut.n. bactrum a rod; M.L. masc.n. Lysobacter the loosing rod; intended to mean the lysing rod.)

Flexible, gliding, gram-negative rods, 0.2 to 0.5 by 2 to $70 \mu \mathrm{m}$. Colonies are slimy or mucoid and are white, cream, yellow, pink or brown; many strains also produce a brown water-soluble pigment; the nature of the pigments is unknown. Growth in broth culture is silky.

Aerobic; mesophilic; $\mathrm{pH}$ range for growth, 5 to 10 ; growth of most strains is reduced by $1 \%$ $\mathrm{NaCl}$.

Chemoorganotrophic. Metabolism is usually respiratory; molecular oxygen is used as the terminal electron acceptor.

$\mathrm{NO}_{3}{ }^{-}, \mathrm{NH}_{4}^{+}$, glutamate, and asparaginate are used as $\mathbf{N}$ sources.

Chitin, but not filter-paper cellulose or agar, is hydrolyzed.

Strongly proteolytic.

Catalase, oxidase, and phosphatase are produced. The indole, MR, and VP tests are negative.

Lyses gram-negative, gram-positive (including actinomycetes), and blue-green bacteria, filamentous fungi, yeasts, and algae; also lyses nematodes.

Habitat: Soil and fresh water.

The $\mathrm{G}+\mathrm{C}$ content of the DNA ranges from 65.4 to $70.1 \mathrm{~mol} \%$. 
TABLE 3. Colonial characteristics of Lysobacter strains on CCA after 5 days of incubation

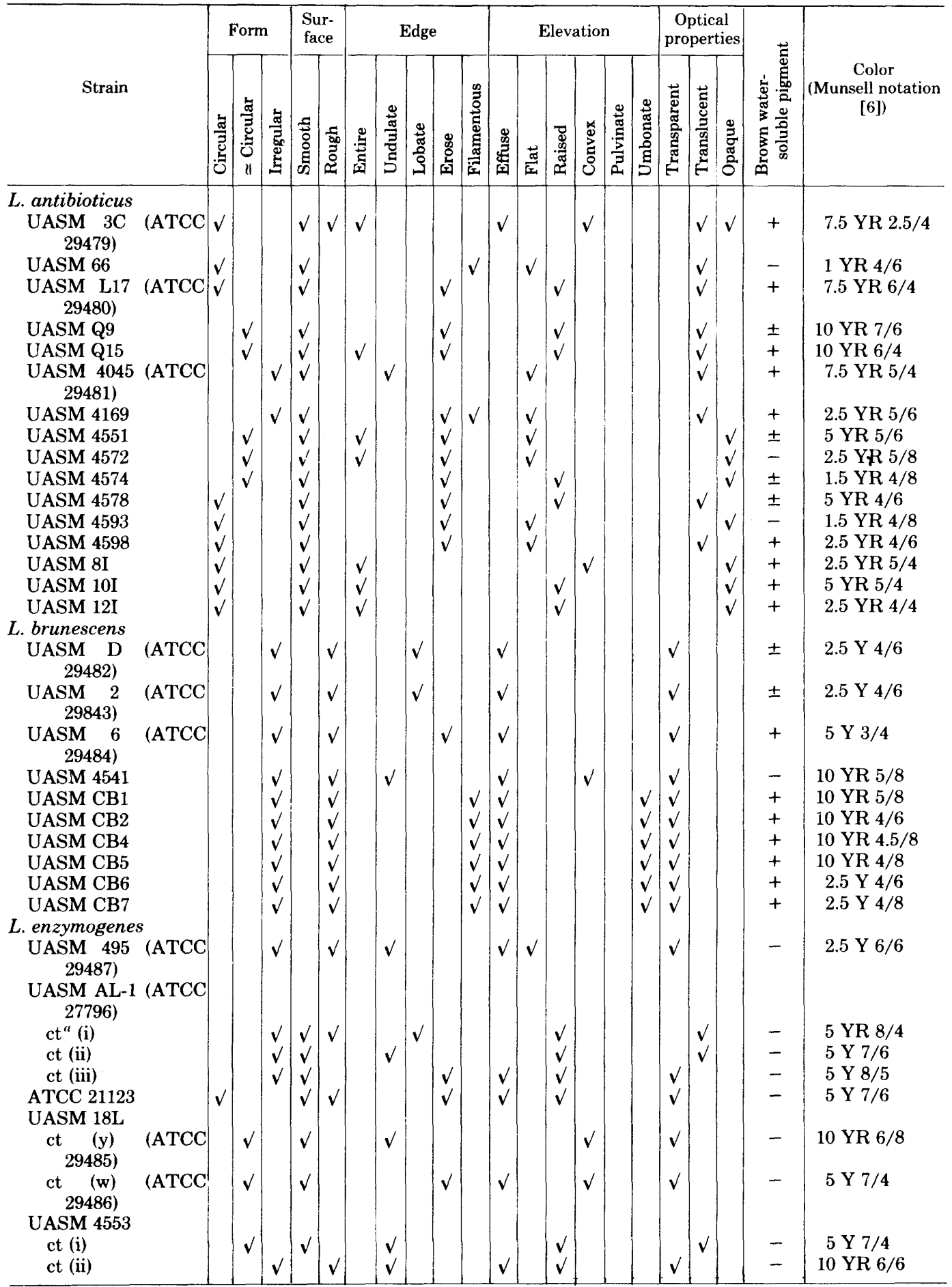


TABLE 3-Continued

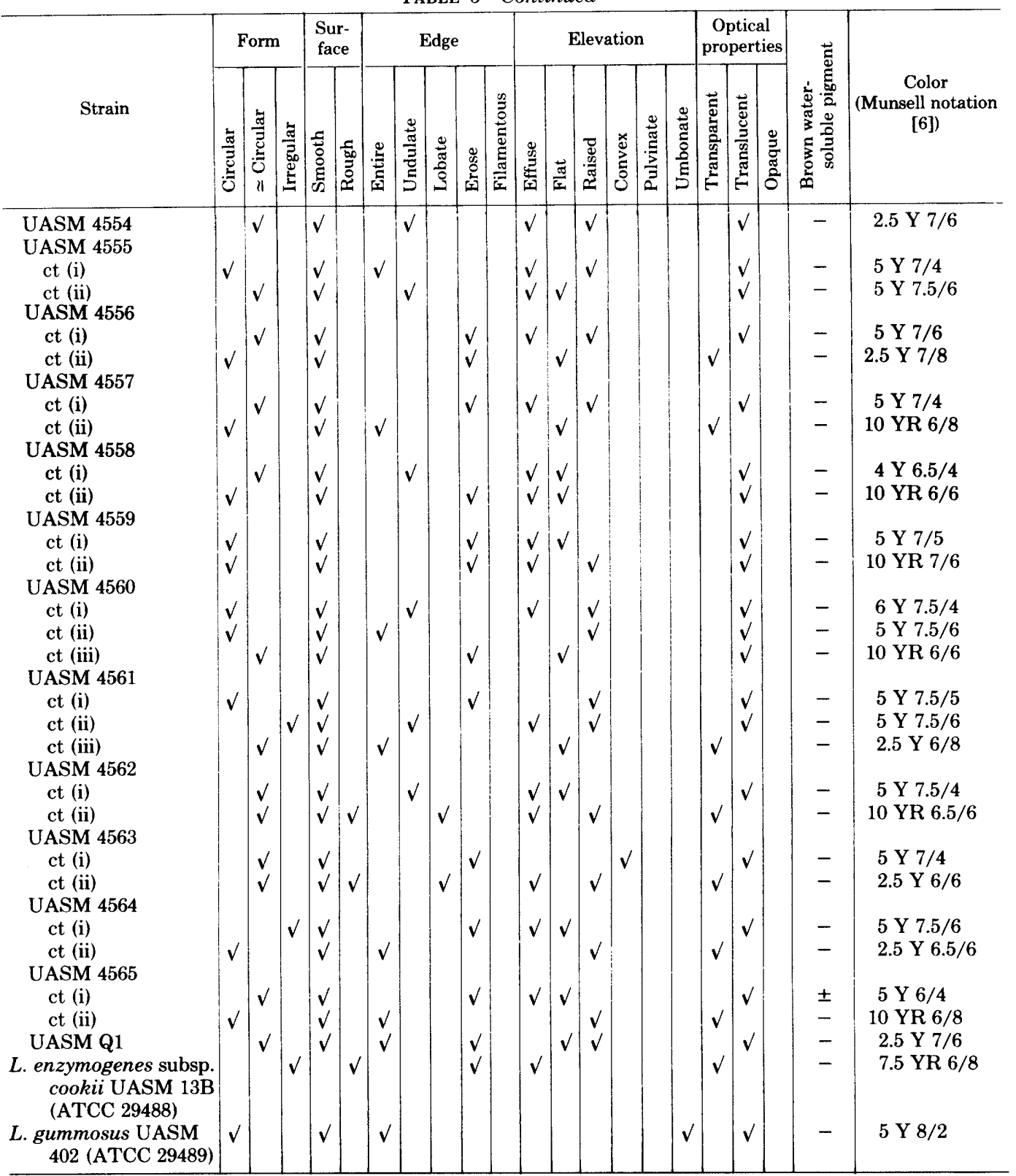

${ }^{a}$ ct, Colony type.

Type species: Lysobacter enzymogenes.

Comments: Two strains, each belonging to a different species in this genus, have been the subjects of considerable interest. Strain UASM 3C (= ATCC 29479) of L. antibioticus produces the antibiotic myxin (4, 19-21, 27, Cook et al., U. S. Patent $3,609,153,1971)$, and important proteolytic enzymes are produced by $L$. enzym. ogenes strain UASM 495 (= ATCC 29487) (1,
$10,14,24,38-42)$ and by strain UASM AL-1 (= ATCC 27796) (12, 13, 15-17; Huang and Ensign, Bacteriol. Proc., P22, p. 127, 1971). In addition, ultrastructure studies have shown the presence in strain UASM AL-1 of rhapidosomes (25) and the absence of a ruthenium red-stainable acid mucopolysaccharide outer layer in contrast to three fruiting myxobacters studied. Sohre studied intracellular hydrolytic enzymes in UASM 
TABLE 4. Colonial characteristics of Lysobacter strains on SAA after 5 days of incubation

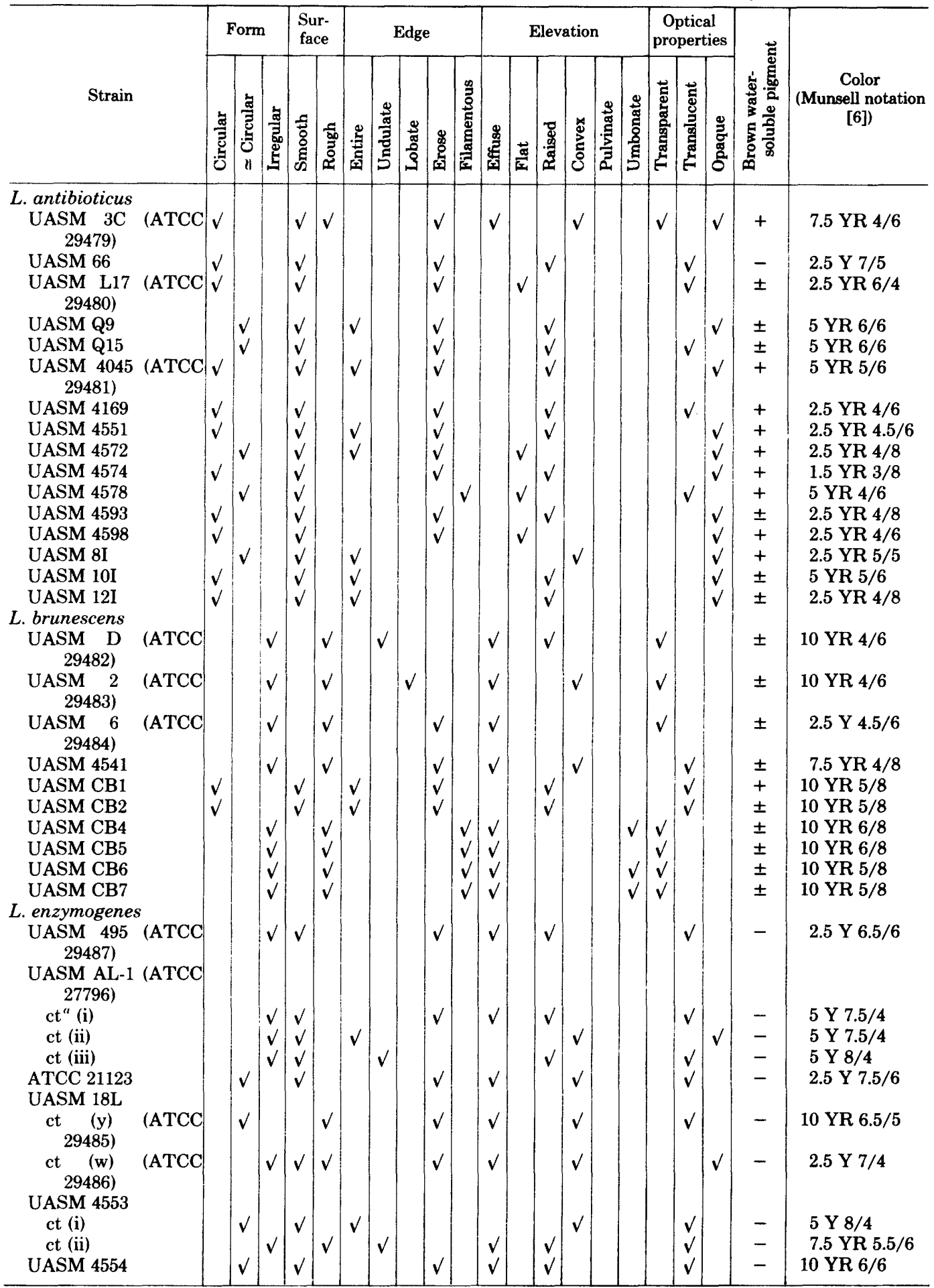




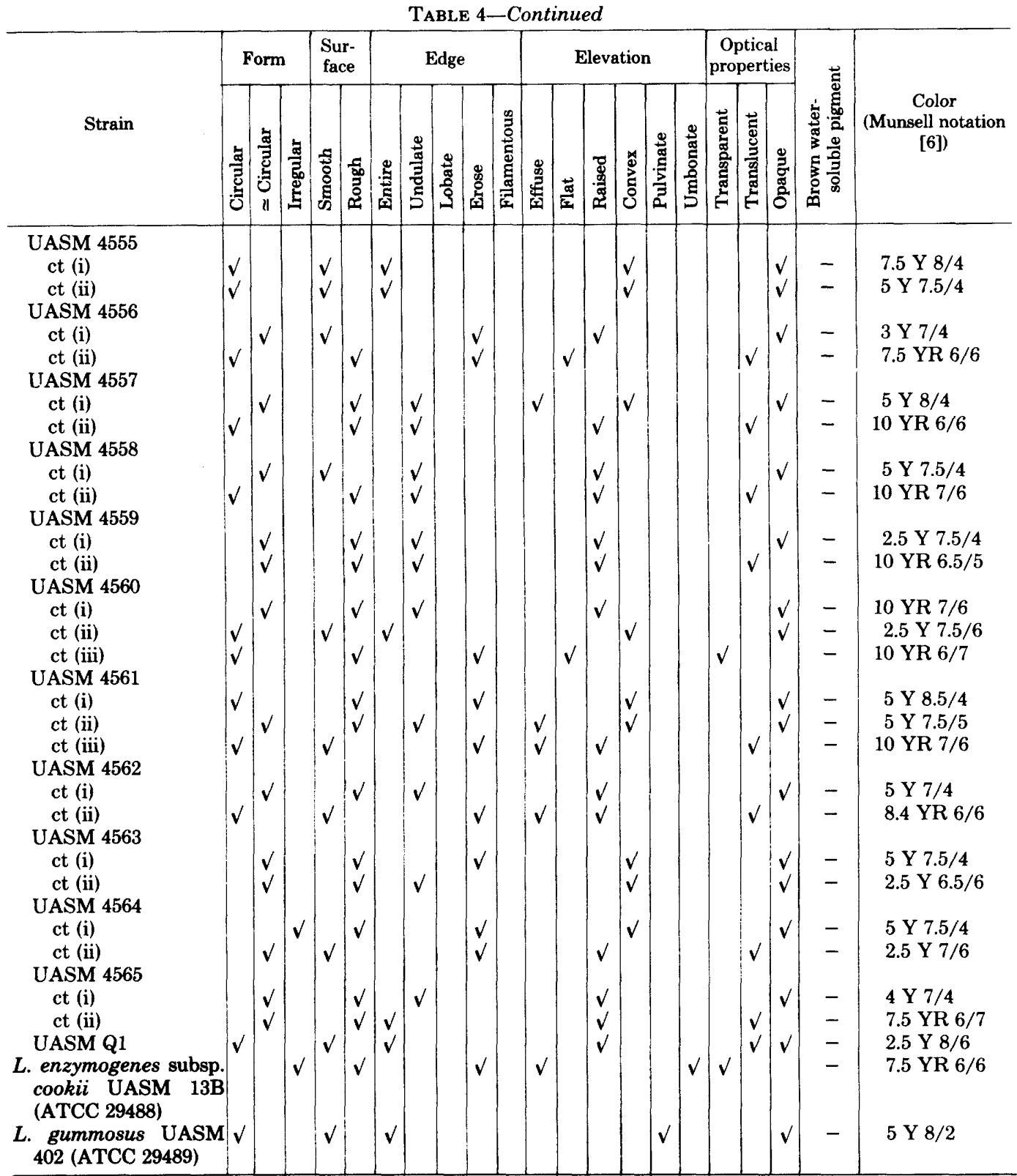

${ }^{a}$ ct, Colony type.

AL-1 (I. Sohre, Ph.D. thesis, University of Karlsruhe, Karlsruhe, Federal Republic of Germany, 1971), and she also reported on the cell cycle in this strain (37). Sendecki et al. investigated the ribosomes of strain UASM 495 (29).

One of the outstanding characteristics of lysobacters is their ability to hydrolyze chitin. Indeed, isolation of these organisms is facilitated by providing chitin as a suspension, in ground mushrooms, or in autoclaved yeast cells (see Materials and Methods).

Soriano's creamy-white, mucoid Flexibacter albuminosus and $F$. aureus (33) may belong in Lysobacter; however, neither their use of chitin, CMC, and alginate nor their lytic abilities were tested by Soriano, and no cultures of these organisms are known to be available; thus it is impossible to assess them further. 
TABLE 5. Colonial characteristics of Lysobacter strains on PCA after 5 days of incubation

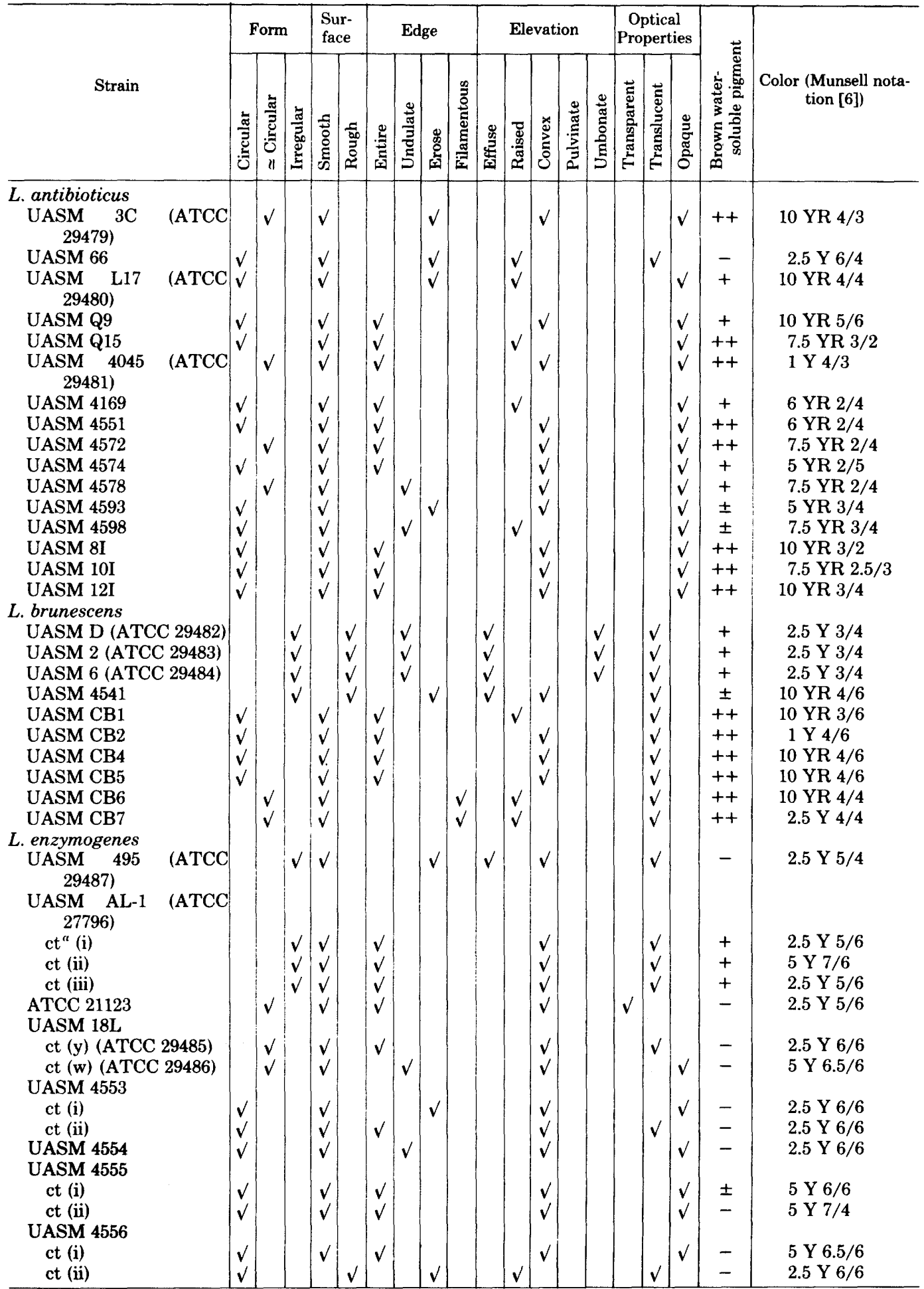


TABLE 5-Continued

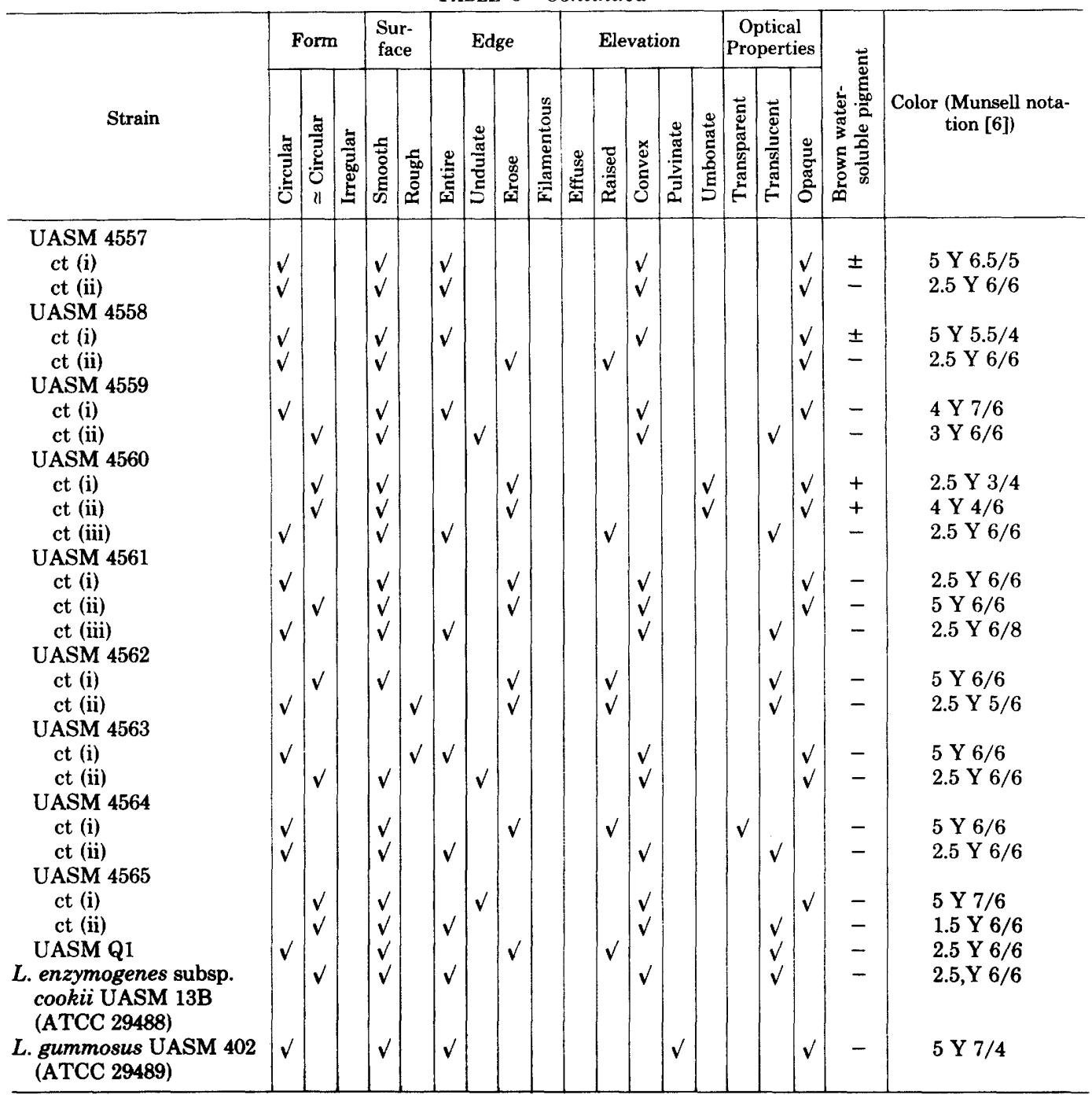

${ }^{n}$ ct, Colony type.

The 46 isolates studied here fell into four groups on the basis of colony color and other characteristics (Table 12). These groups are here regarded as separate species, as follows.

1a. Lysobacter enzymogenes subsp. enzymogenes sp. nov. and subsp. nov. (en.zy.mo'ge.nes. Gr. noun zyme leaven; M.L. noun enzymum enzyme; Gr.v. gennaio to produce; M.L. adj. enzymogenes enzyme-producing).

Flexible rods 0.3 to 0.5 by 4 to $50 \mu \mathrm{m}$ (Fig. 3).

Two distinct colony types are known: a dirtywhite mucoid colony and a yellowish nonmucoid one. The mucoid colony produces nonmucoid mutants, but the yellowish, nonmucoid colony type does not produce revertants to the dirty white, mucoid type. The following colony descriptions cover the whole range of colony types observed. The types are identical in other properties.

On CCA, 5-day-old colonies are dark cream; circular to irregular; usually with a smooth, but occasionally rough, surface; edge may be entire, undulate, lobate or erose; elevation effuse, flat, or raised, occasionally convex; transparent or translucent; no brown water-soluble pigment is produced.

On SAA, 5-day-old colonies are dark cream; circular to irregular; with a smooth or rough surface; edge may be entire, undulate or erose; elevation effuse, raised, or convex, occasionally 
TABLE 6. Physiology of Lysobacter strains: growth requirements

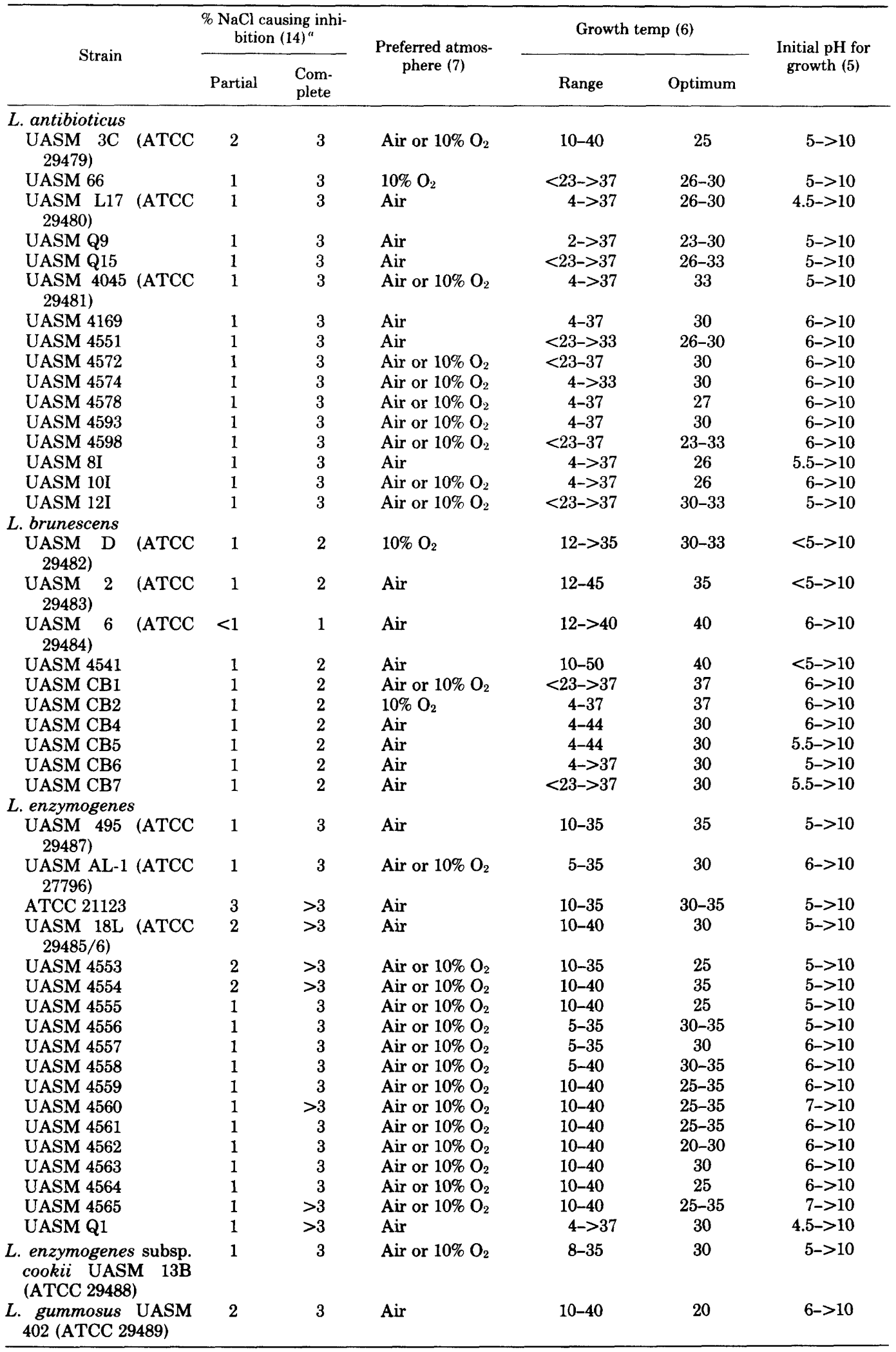

\footnotetext{
${ }^{a}$ Numbers in parentheses are days of incubation.
} 
TABLE 7. Physiology of Lysobacter strains: antibiotic susceptibilities ${ }^{a}$

\begin{tabular}{|c|c|c|c|c|c|c|c|c|}
\hline \multirow{2}{*}{ Strain } & \multicolumn{2}{|c|}{$\begin{array}{l}\text { \% SLS at which } \\
\text { growth is }\end{array}$} & \multirow{2}{*}{$\begin{array}{c}\text { Chloram- } \\
\text { phenicol } \\
(30 \mu \mathrm{g})\end{array}$} & \multirow{2}{*}{$\begin{array}{l}\text { Strepto- } \\
\text { mycin (10 } \\
\mu \mathrm{g})\end{array}$} & \multirow{2}{*}{$\begin{array}{l}\text { Penicillin } \\
\text { G (10 U) }\end{array}$} & \multicolumn{2}{|c|}{ Polymyxin B (300 U) } & \multirow{2}{*}{$\begin{array}{l}\text { Actino- } \\
\text { mycin D }\end{array}$} \\
\hline & Reduced & Inhibited & & & & $\begin{array}{l}\text { Kirby- } \\
\text { Bauer }\end{array}$ & $\begin{array}{l}\text { Author's } \\
\text { scheme }\end{array}$ & \\
\hline \multicolumn{9}{|l|}{ L. antibioticus } \\
\hline UASM 3C (ATCC 29479) & $>0.01$ & 0.1 & $\mathbf{R}$ & $\mathbf{R}$ & $\mathbf{R}$ & I & $\mathbf{S}$ & - \\
\hline UASM 66 & $>0.01$ & 0.1 & $\mathbf{S}$ & $\mathbf{S}$ & $\mathrm{R}$ & I & $\mathbf{S}$ & $\mathrm{R}$ \\
\hline UASM L17 (ATCC 29480) & $>0.01$ & 0.1 & $\mathbf{R}$ & $\mathbf{R}$ & $\mathbf{R}$ & I & $\mathbf{S}$ & $\mathbf{R}$ \\
\hline UASM Q9 & $>0.01$ & $>0.1$ & $\mathbf{R}$ & $\mathbf{R}$ & $\mathbf{R}$ & I & $\mathbf{S}$ & $\mathbf{R}$ \\
\hline UASM Q15 & $>0.01$ & 0.1 & $\mathbf{R}$ & $\mathbf{R}$ & $\mathbf{R}$ & $\mathrm{R}$ & $\mathbf{S}$ & $\mathbf{R}$ \\
\hline UASM 4045 (ATCC 29481) & $>0.01$ & 0.1 & $\mathbf{R}$ & $\mathbf{R}$ & $\mathrm{R}$ & $\mathbf{R}$ & $\mathbf{S}$ & $\mathbf{R}$ \\
\hline UASM 4169 & $>0.01$ & 0.1 & $\mathrm{R}$ & $\mathbf{R}$ & $\mathrm{R}$ & I & $\mathbf{S}$ & $\mathbf{R}$ \\
\hline UASM 4551 & $>0.01$ & 0.1 & $\mathbf{R}$ & $\mathbf{R}$ & $\mathrm{R}$ & I & $\mathbf{S}$ & $\mathbf{R}$ \\
\hline UASM 4572 & $>0.01$ & 0.1 & $\mathbf{R}$ & I & $\mathbf{R}$ & I & $\mathbf{S}$ & $\mathbf{R}$ \\
\hline UASM 4574 & $>0.01$ & 0.1 & $\mathrm{R}$ & $\mathbf{R}$ & $\mathbf{R}$ & I & $\mathbf{S}$ & $\mathbf{R}$ \\
\hline UASM 4578 & $>0.01$ & 0.1 & $\mathrm{R}$ & $\mathbf{R}$ & $\mathrm{R}$ & $\mathrm{R}$ & $\mathrm{S}$ & $\mathbf{R}$ \\
\hline UASM 4593 & $>0.01$ & 0.1 & $\mathbf{R}$ & $\mathbf{R}$ & $\mathbf{R}$ & I & $\mathbf{S}$ & $\mathbf{R}$ \\
\hline UASM 4598 & $>0.01$ & 0.1 & $\mathrm{R}$ & I & $\mathbf{R}$ & I & $\mathbf{S}$ & $\mathbf{R}$ \\
\hline UASM 8I & $>0.01$ & 0.1 & $\mathrm{R}$ & $\mathbf{R}$ & $\mathrm{R}$ & $\mathbf{R}$ & I & $\mathbf{R}$ \\
\hline UASM 10I & $>0.01$ & 0.1 & $\mathrm{R}$ & $\mathbf{R}$ & $\mathrm{R}$ & I & $\mathbf{S}$ & $\mathbf{R}$ \\
\hline UASM $12 \mathrm{I}$ & $>0.01$ & 0.1 & $\mathbf{R}$ & $\mathbf{R}$ & $\mathrm{R}$ & I & $\mathbf{S}$ & $\mathbf{R}$ \\
\hline \multicolumn{9}{|l|}{ L. brunescens } \\
\hline UASM D (ATCC 29482) & 0.01 & 0.1 & $\mathbf{S}$ & $\mathbf{S}$ & $\mathbf{S}$ & I & $\mathbf{S}$ & $\mathbf{S}$ \\
\hline UASM 2 (ATCC 29483) & 0.01 & 0.1 & $\mathbf{S}$ & $\mathbf{S}$ & $\mathrm{S}$ & $\mathrm{I}$ & $\mathrm{S}$ & $\mathrm{S}$ \\
\hline UASM 6 (ATCC 29484) & 0.01 & 0.1 & $\mathbf{S}$ & $\mathbf{S}$ & $\mathrm{I}$ & $\mathrm{I}$ & $\mathbf{S}$ & $\mathbf{S}$ \\
\hline UASM 4541 & $>0.01$ & 0.1 & $\overline{\mathbf{S}}$ & I & $\mathrm{I}$ & $\mathrm{I}$ & $\mathbf{S}$ & $\mathbf{S}$ \\
\hline UASM CB1 & 0.01 & 0.1 & $\mathrm{~S}$ & $\mathrm{I}$ & $\mathrm{S}$ & - & - & $\mathbf{S}$ \\
\hline UASM CB2 & 0.01 & 0.1 & $\mathbf{S}$ & $\mathbf{S}$ & $\mathbf{S}$ & - & - & $\mathbf{S}$ \\
\hline UASM CB4 & $>0.01$ & 0.1 & $\mathbf{S}$ & $\mathbf{S}$ & $\mathbf{S}$ & - & - & $\mathbf{S}$ \\
\hline UASM CB5 & $>0.01$ & 0.1 & $\mathbf{S}$ & $\mathbf{S}$ & $\mathbf{S}$ & - & - & $\mathbf{S}$ \\
\hline UASM CB6 & $>0.01$ & 0.1 & $\mathbf{S}$ & I & $\mathbf{S}$ & - & - & $\mathbf{S}$ \\
\hline UASM CB7 & $>0.01$ & 0.1 & $\mathbf{S}$ & $\mathbf{R}$ & $\mathbf{S}$ & - & - & $\mathbf{S}$ \\
\hline \multicolumn{9}{|l|}{ L. enzymogenes } \\
\hline UASM 495 (ATCC 29487) & 0.01 & 0.1 & $\mathbf{S}$ & $\mathbf{R}$ & $\mathbf{R}$ & $\mathrm{I}$ & $\mathbf{S}$ & I \\
\hline UASM AL-1 (ATCC 27796) & 0.01 & $>0.1$ & $\tilde{R}$ & $\mathbf{R}$ & $\mathrm{R}$ & $\mathrm{R}$ & $\mathbf{S}$ & $\mathrm{I}$ \\
\hline ATCC 21123 & $>0.01$ & $>0.1$ & $\mathrm{I}$ & $\mathbf{R}$ & $\mathrm{R}$ & $\mathrm{R}$ & $\mathbf{S}$ & - \\
\hline $\begin{array}{l}\text { UASM 18L (ATCC 29485/ } \\
6 \text { ) }\end{array}$ & $>0.01$ & 0.1 & $\mathrm{I}$ & $\mathbf{R}$ & $\mathbf{R}$ & $\mathbf{R}$ & $\mathbf{S}$ & - \\
\hline UASM 4553 & $>0.01$ & $>0.1$ & $\mathbf{R}$ & $\mathbf{R}$ & $\mathrm{R}$ & I & $\mathbf{S}$ & $\mathbf{R}$ \\
\hline UASM 4554 & $>0.01$ & 0.1 & $\mathbf{S}$ & $\mathrm{R}$ & $\mathrm{R}$ & $\mathrm{R}$ & $\mathbf{S}$ & I \\
\hline UASM 4555 & $>0.01$ & $>0.1$ & $\mathbf{S}$ & $\mathbf{R}$ & $\mathbf{R}$ & $\mathbf{R}$ & $\mathbf{S}$ & I \\
\hline UASM 4556 & $>0.01$ & $>0.1$ & $\mathrm{R}$ & $\mathbf{R}$ & $\mathrm{R}$ & I & $\mathbf{S}$ & $\mathbf{R}$ \\
\hline UASM 4557 & $>0.01$ & $>0.1$ & I & $\mathrm{R}$ & $\mathrm{R}$ & $\bar{I}$ & $\mathbf{S}$ & $\mathbf{R}$ \\
\hline UASM 4558 & $>0.01$ & $>0.1$ & $\mathbf{R}$ & $\mathbf{R}$ & $\mathrm{R}$ & $\mathrm{R}$ & $\mathbf{S}$ & I \\
\hline UASM 4559 & $>0.01$ & $>0.1$ & $\mathbf{R}$ & $\mathbf{R}$ & $\mathbf{R}$ & $\mathrm{R}$ & $\mathbf{S}$ & I \\
\hline UASM 4560 & $>0.01$ & $>0.1$ & $\mathbf{S}$ & $\mathrm{R}$ & $\mathrm{R}$ & I & $\mathrm{S}$ & I \\
\hline UASM 4561 & $>0.01$ & $>0.1$ & $\mathbf{R}$ & I & $\mathbf{R}$ & $\mathbf{R}$ & $\mathbf{S}$ & I \\
\hline UASM 4562 & $>0.01$ & $>0.1$ & I & $\mathrm{R}$ & $\mathrm{R}$ & $\mathrm{R}$ & $\mathbf{S}$ & I \\
\hline UASM 4563 & $>0.01$ & $>0.1$ & I & $\mathrm{R}$ & $\mathrm{R}$ & $\mathbf{R}$ & $\mathbf{S}$ & $\mathbf{R}$ \\
\hline UASM 4564 & $>0.01$ & 0.1 & $\mathrm{R}$ & $\mathrm{R}$ & $\mathrm{R}$ & $\mathrm{R}$ & $\mathbf{S}$ & $\mathrm{R}$ \\
\hline UASM 4565 & $>0.01$ & $>0.1$ & 1 & $\mathrm{R}$ & $\mathrm{R}$ & I & $\mathbf{S}$ & $\mathrm{R}$ \\
\hline UASM Q1 & $>0.01$ & $>0.1$ & $\mathbf{R}$ & $\mathbf{R}$ & $\mathbf{R}$ & $\mathbf{R}$ & $\mathbf{S}$ & $\mathrm{R}$ \\
\hline $\begin{array}{l}\text { L. enzymogenes subsp. cookii } \\
\text { UASM 13B (ATCC } \\
\text { 29488) }\end{array}$ & 0.01 & 0.1 & $\mathbf{S}$ & $\mathbf{R}$ & $\mathrm{R}$ & I & $\mathbf{S}$ & I \\
\hline $\begin{array}{l}\text { L. gummosus UASM } 402 \\
\text { (ATCC 29489) }\end{array}$ & $>0.01$ & $>0.1$ & $\mathrm{R}$ & $\mathbf{R}$ & $R$ & I & $\mathbf{S}$ & I \\
\hline
\end{tabular}

${ }^{a}$ All read at 2 days except SLS which was read at 5 days. Abbreviations: S, susceptible; I, intermediate; $R$, resistant; -, not done. Columns 3 through 6 are scored by the Kirby-Bauer scheme (3). Column 7 is scored on the author's scheme based on the behavior of control organisms Escherichia coli, Pseudomonas aeruginosa, Arthrobacter sp., Serratia marcescens, and Bacillus subtilis (see Table 1). Column 8 is scored in comparison to control organisms $E$. coli and $B$. subtilis: $\mathrm{S}$, more susceptible than $E$. coli but not so susceptible as $B$. subtilis; R, same as or less susceptibility than $E$. coli, i.e., resistant. Early and late observations were made at 2 and 3 days, respectively. 
TABLE 8. Physiology of Lysobacter strains: antimicrobial lytic action ${ }^{\prime \prime}$

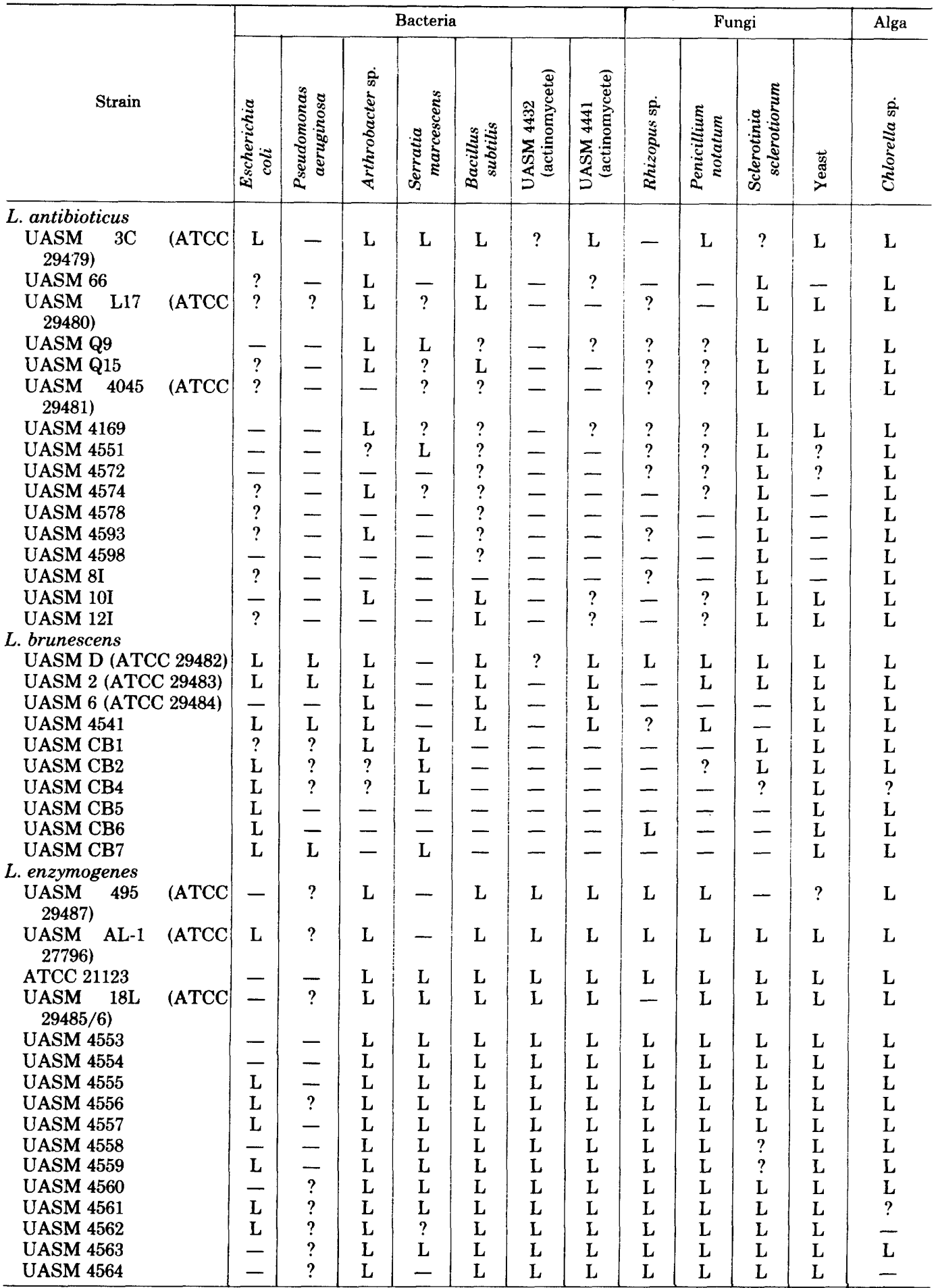


TABLE 8-Continued

\begin{tabular}{|c|c|c|c|c|c|c|c|c|c|c|c|c|}
\hline \multirow[b]{2}{*}{ Strain } & \multicolumn{7}{|c|}{ Bacteria } & \multicolumn{4}{|c|}{ Fungi } & \multirow{2}{*}{ 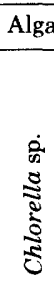 } \\
\hline & 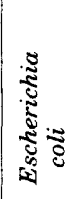 & 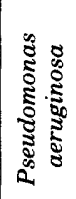 & 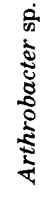 & 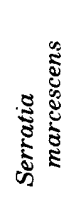 & 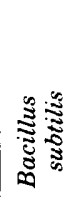 & 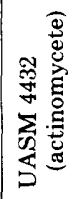 & 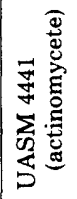 & 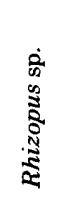 & 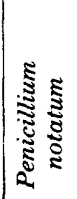 & 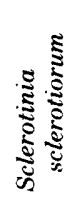 & $\begin{array}{l}\overrightarrow{\mathrm{g}} \\
\stackrel{\mathrm{g}}{2}\end{array}$ & \\
\hline $\begin{array}{l}\text { UASM } 4565 \\
\text { UASM Q1 }\end{array}$ & $\bar{L}$ & $\overline{-}$ & $\begin{array}{l}\mathrm{L} \\
\mathrm{L}\end{array}$ & $\begin{array}{l}\mathrm{L} \\
\mathrm{L}\end{array}$ & $\begin{array}{l}\mathrm{L} \\
?\end{array}$ & L & L & $\begin{array}{l}\mathrm{L} \\
\mathrm{L}\end{array}$ & $\begin{array}{l}\mathrm{L} \\
\mathrm{L}\end{array}$ & $\begin{array}{l}\mathrm{L} \\
\mathrm{L}\end{array}$ & $\begin{array}{l}\mathrm{L} \\
\mathrm{L}\end{array}$ & $\begin{array}{l}\mathrm{L} \\
\mathrm{L}\end{array}$ \\
\hline $\begin{array}{l}\text { L. enzymogenes subsp. } \\
\text { cookii UASM 13B } \\
\text { (ATCC 29488) }\end{array}$ & - & - & $\mathrm{L}$ & - & $\mathrm{L}$ & $\mathbf{L}$ & $\mathrm{L}$ & $\mathrm{L}$ & $\mathrm{L}$ & - & $\mathrm{L}$ & \\
\hline $\begin{array}{l}\text { L. gummosus UASM } 402 \\
\text { (ATCC 29489) }\end{array}$ & - & - & L & - & $\mathrm{L}$ & L & $\mathrm{L}$ & $?$ & $\mathrm{~L}$ & $\mathrm{~L}$ & $\mathrm{~L}$ & $\mathrm{~L}$ \\
\hline
\end{tabular}

"Results were read after 11 days except for the yeast, whose results were read at 9 days. Maximum lytic activity in each test noted as: L, good lysis; ?, possible lysis; -, no lysis.

flat; translucent or opaque; no brown, watersoluble pigment is produced.

On PCA, 5-day-old colonies are deep yellow cream; more or less circular; usually with a smooth surface; edge may be entire, undulate or erose; elevation mainly convex, sometimes raised or umbonate; translucent or opaque; some water-soluble pigment is produced.

Older cultures on most media produce copious, dark brown, water-soluble pigment.

Growth of 15 of 18 strains is reduced by $1 \%$ $\mathrm{NaCl}$, and growth of 12 of 18 is inhibited by $3 \%$ $\mathrm{NaCl}$; preferred atmosphere, air or $10 \% \mathrm{O}_{2}$; temperature range for growth, 5 to $40^{\circ} \mathrm{C}$; temperature for optimum growth, 25 to $35^{\circ} \mathrm{C}$.

Two of 18 strains utilize urea as $\mathrm{N}$ source.

Growth of 16 of 18 strains is not reduced by $0.01 \%$ sodium lauryl sulfate (SLS), and only three of 18 strains are inhibited completely by $0.1 \%$ SLS. Resistant to $10 \mu \mathrm{g}$ of streptomycin and to $10 \mathrm{U}$ of penicillin, susceptible to $300 \mathrm{U}$ of polymyxin $\mathrm{B}$, resistant or intermediate in response to actinomycin $\mathrm{D}$, and variable in response to $30 \mu \mathrm{g}$ of chloramphenicol.

Ninety percent or more of the isolates lyse gram-positive bacteria (including actinomycetes), filamentous fungi, a yeast, and a green alga. Less than $50 \%$ of the isolates lyse gramnegative bacteria.

Attack on glucose is oxidative, and in 1 strain of 18 it is also fermentative. Acid is produced from glucose, cellobiose, sucrose, and lactose. Fifteen of 18 strains produce acid from glycerol and from mannitol.

Lipase activity is shown on Tweens $20,40,60$, and 80 .

Hydrolyzes alginate, pectate, and CMC but not starch.

Liquefies gelatin; peptonizes milk in 1 to 2 days; growth and $\mathrm{NH}_{3}$ are produced from casein, Penassay, Casitone, and Casamino Acids broths; grows well on $0.2 \%$ tryptone agar; 17 of 18 strains show beta-, and one strain shows alpha-hemolysis.

Three of 18 strains produce $\mathrm{H}_{2} \mathrm{~S}$; colorless colonies are produced on MacConkey agar; pink colonies are produced on EMB: the citrate test is positive.

Does not reduce $\mathrm{NO}_{3}{ }^{-}$or $\mathrm{NO}_{2}^{-}$.

Habitat: Soil.

The $\mathrm{G}+\mathrm{C}$ content of the DNA ranges from 69.0 to $70.1 \mathrm{~mol} \%$; that of the type strain is 69.0 $\mathrm{mol} \%\left(T_{m}\right)$.

Type strain: UASM 495 (= ATCC 29487).

1b. Lysobacter enzymogenes subsp. cookii Christensen subsp. nov. (coo'ki.i. M.L. gen.n. cookii of Cook; named for F. D. Cook, the microbiologist who first isolated lysobacters and who recognized their lytic and antibiotic potentials).

Description as for L. enzymogenes subsp. enzymogenes, with the following exceptions.

Colonies on CCA are creamy brown and irregular with rough surfaces.

Colonies on SAA are creamy brown, irregular, and transparent.

Colonies on PCA are creamy brown with no water-soluble pigment.

The production of brown water-soluble pigment is not so marked, although it was observed on three media.

Preferred atmosphere is air; temperature range for growth, 8 to $35^{\circ} \mathrm{C}$; temperature for optimum growth, $20^{\circ} \mathrm{C} ; \mathrm{pH}$ range for growth, 6 to $>10$.

Utilizes urea as $\mathbf{N}$ source.

Growth is reduced by $0.01 \%$ SLS and com- 


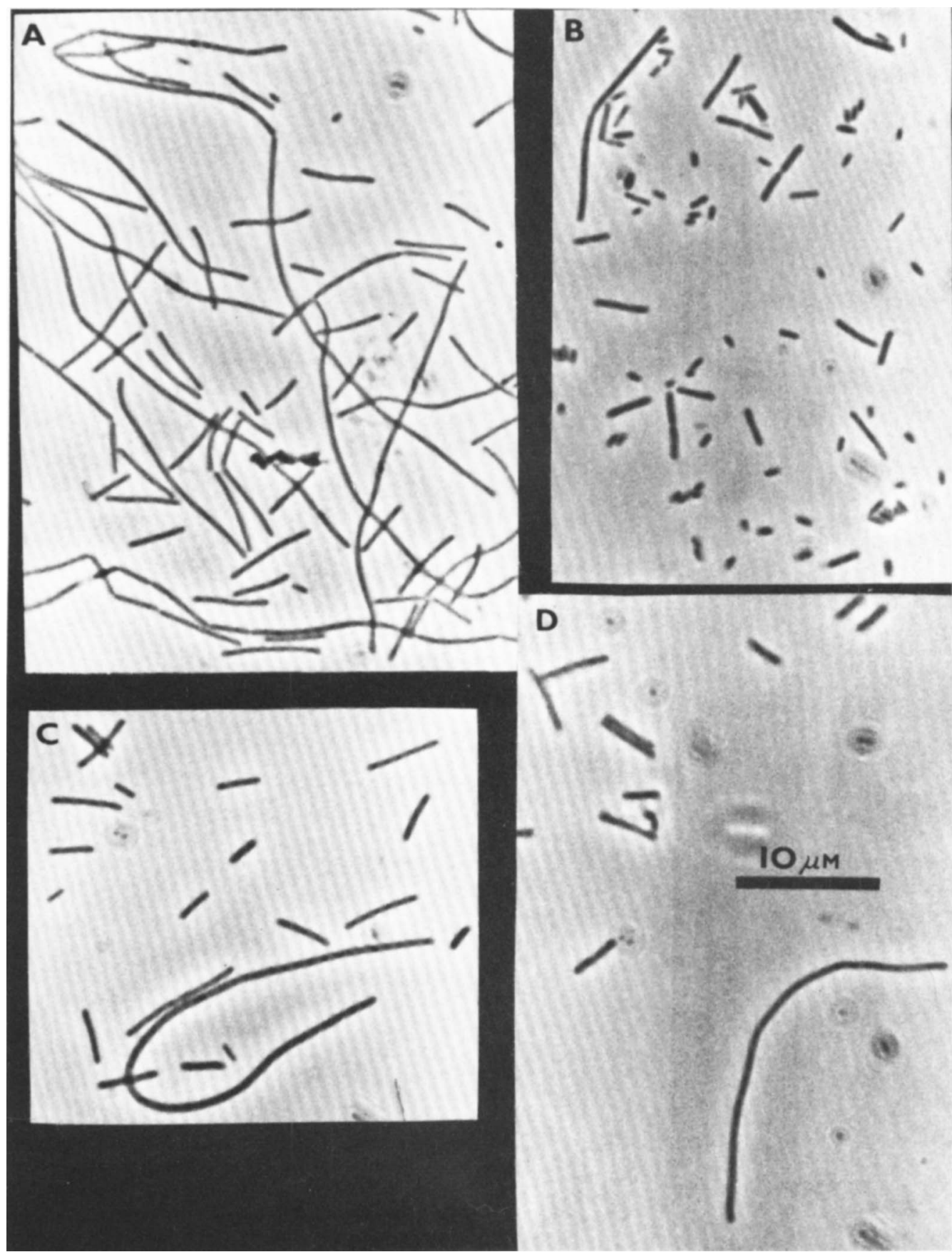

FIG. 3. Cells of Lysobacter enzymogenes from skim acetate broth cultures. (A) UASM 495 (= ATCC 29487), $44 h$; (B) ATCC 21123, $44 h$; (C) UASM 18 LW (= ATCC 29485), $44 h$; (D) L. enzymogenes subsp. cookii UASM $13 B$ (= ATCC 29488), $60 \mathrm{~h}$. All micrographs are at the same magnification.

pletely inhibited by $0.1 \%$ SLS. Intermediate reaction to actinomycin D; susceptible to $30 \mu \mathrm{g}$ of chloramphenicol.

Does not lyse gram-negative bacteria.
Does not produce acid from glycerol or mannitol.

Hydrolyzes starch but not alginate.

Alpha-hemolytic. 
TABLE 9. Biochemical reactions of Lysobacter strains: sugars, alcohols, lipids, polysaccharides ${ }^{a}$

\begin{tabular}{|c|c|c|c|c|c|c|c|c|c|c|c|c|c|c|c|c|c|}
\hline \multirow[b]{3}{*}{ Strain } & \multicolumn{2}{|c|}{$\begin{array}{l}\text { OF test with glu- } \\
\text { cose }(15)^{b}\end{array}$} & \multicolumn{5}{|c|}{ Acid production from: (17) } & \multicolumn{4}{|c|}{ Lipase activity (5) } & \multicolumn{6}{|c|}{ Polysaccharide hydrolysis } \\
\hline & \multirow[b]{2}{*}{ 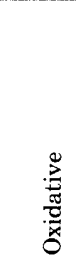 } & \multirow[b]{2}{*}{ 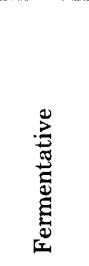 } & \multirow[b]{2}{*}{$\frac{\mathscr{v}}{0.0}$} & \multirow[b]{2}{*}{ 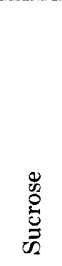 } & \multirow[b]{2}{*}{ 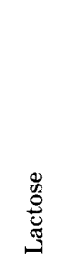 } & \multirow[b]{2}{*}{$\begin{array}{l}\overrightarrow{0} \\
\stackrel{0}{0}\end{array}$} & \multirow[b]{2}{*}{ 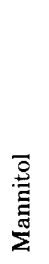 } & \multirow[b]{2}{*}{ 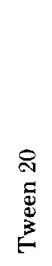 } & \multirow[b]{2}{*}{$\begin{array}{l}\mathcal{F} \\
\mathbb{J} \\
3 \\
3\end{array}$} & \multirow[b]{2}{*}{$\begin{array}{l}8 \\
8 \\
8 \\
0 \\
3 \\
3\end{array}$} & \multirow[b]{2}{*}{ 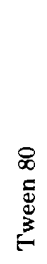 } & \multirow[b]{2}{*}{ 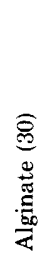 } & \multirow[b]{2}{*}{ 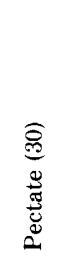 } & \multirow[b]{2}{*}{ 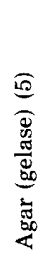 } & \multicolumn{3}{|c|}{ Starch } \\
\hline & & & & & & & & & & & & & & & 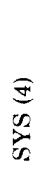 & 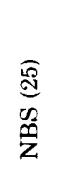 & $\begin{array}{l}\hat{0} \\
0 \\
0 \\
0 \\
0 \\
0\end{array}$ \\
\hline \multicolumn{18}{|l|}{ L. antibioticus } \\
\hline UASM 3C (ATCC 29479) & + & - & + & - & - & - & - & - & \pm & \pm & + & - & $-\mathrm{g}$ & - & - & $-\mathrm{g}$ & - \\
\hline UASM 66 & + & $\begin{array}{c}+ \\
\text { slow }\end{array}$ & + & - & - & - & $\dot{-}$ & + & \pm & + & + & + & & & & - & \\
\hline UASM L17 (ATCC 29480) & + & - & + & - & - & - & - & + & \pm & + & + & - & $-\mathrm{g}$ & & & - & \\
\hline UASM Q9 & + & - & + & + & + & + & + & + & + & + & + & + & $\begin{array}{l}-\mathrm{g} \\
-\mathrm{g}\end{array}$ & & & - & \\
\hline UASM Q15 & + & $\begin{array}{c}+ \\
\text { slow }\end{array}$ & $\begin{array}{c}+ \\
\text { weak }\end{array}$ & - & - & - & - & + & + & + & + & - & $-\mathrm{g}$ & & & - & \\
\hline UASM 4045 (ATCC 29481) & + & $\begin{array}{c}+ \\
\text { slow }\end{array}$ & + & - & - & - & - & + & + & + & + & - & $-\mathrm{g}$ & & & - & \\
\hline UASM 4169 & + & $\begin{array}{c}+ \\
\text { slow }\end{array}$ & + & - & - & - & - & - & \pm & \pm & + & - & $-\mathrm{g}$ & & & - & \\
\hline UASM 4551 & + & + & + & - & - & - & - & - & \pm & + & + & - & $-\mathrm{g}$ & & & - & \\
\hline UASM 4572 & + & $\stackrel{+}{\text { slow }}$ & + & - & - & - & - & + & \pm & + & + & - & $-\mathrm{g}$ & & & - & \\
\hline UASM 4574 & + & + & $\begin{array}{c}+ \\
\text { weak }\end{array}$ & - & - & - & - & + & + & + & + & - & $-\mathrm{g}$ & & & - & \\
\hline UASM 4578 & + & - & + & - & - & - & - & + & + & + & + & - & $-\mathrm{g}$ & & & - & \\
\hline UASM 4593 & + & $\begin{array}{c}+ \\
\text { slow }\end{array}$ & + & - & - & - & - & + & + & + & + & - & $-g$ & & & - & \\
\hline UASM 4598 & + & $\begin{array}{c}+ \\
\text { slow }\end{array}$ & + & - & + & - & - & + & \pm & + & + & - & $-\mathrm{g}$ & & & - & \\
\hline UASM 8I & + & - & + & - & - & - & - & - & + & \pm & + & + & $-\mathrm{g}$ & & & - & \\
\hline UASM 10I & + & + & + & - & - & - & - & + & + & + & + & - & $-\mathrm{g}$ & & & - & \\
\hline UASM $12 \mathrm{I}$ & + & $\begin{array}{c}+ \\
\text { slow }\end{array}$ & + & - & - & - & - & + & + & + & + & + & $-\mathrm{g}$ & & & - & \\
\hline \multicolumn{18}{|l|}{ L. brunescens } \\
\hline UASM D (ATCC 29482) & + & - & - & - & - & - & - & - & - & \pm & - & - & + & + & + & + & + \\
\hline UASM 2 (ATCC 29483) & + & - & - & - & - & - & - & - & \pm & \pm & + & - & + & + & + & + & + \\
\hline UASM 6 (ATCC 29484) & - & - & - & - & - & - & - & - & - & \pm & - & - & + & + & + & + & + \\
\hline UASM 4541 & + & - & - & - & - & - & - & - & \pm & + & + & - & + & + & + & + & + \\
\hline
\end{tabular}




\begin{tabular}{|c|c|c|c|c|c|c|c|c|c|c|c|c|c|c|c|c|c|}
\hline UASM CB1 & + & - & - & - & - & - & - & - & & & - & - & - & & & + & \\
\hline UASM CB2 & + & - & - & - & - & - & - & - & & & - & - & + & & & + & \\
\hline UASM CB4 & + & - & - & - & - & - & - & - & & & - & - & + & & & $\stackrel{+}{+}$ & \\
\hline UASM CB5 & + & $\stackrel{+}{+}$ & - & - & - & - & - & - & & & - & - & + & & & $\begin{array}{l}+ \\
\text { slow }\end{array}$ & \\
\hline UASM CB6 & + & $\begin{array}{l}+ \\
\text { slow }\end{array}$ & - & - & - & - & - & - & & & - & - & + & & & $\begin{array}{c}+ \\
\text { slow }\end{array}$ & \\
\hline UASM CB7 & $\stackrel{+}{+}$ & $\begin{array}{c}+ \\
\text { slow }\end{array}$ & - & - & - & - & - & - & & & - & - & + & & & $\begin{array}{l}+ \\
\text { slow }\end{array}$ & \\
\hline L. enzymogenes & & & & & & & & & & & & & & & & & \\
\hline UASM 495 (ATCC 29488) & + & - & + & + & + & + & + & + & + & + & + & + & + & & - & $\stackrel{+}{+}$ & - \\
\hline UASM AL-1 (ATCC 27796) & $-\#$ & - & $\begin{array}{c}+ \\
\text { weak }\end{array}$ & - & $\begin{array}{c}+ \\
\text { weak }\end{array}$ & - & - & + & + & + & + & + & + & - & - & - & - \\
\hline ATCC 21123 & + & - & + & + & + & - & - & + & + & + & + & + & + & - & - & - & - \\
\hline UASM 18L (ATCC 29485/6) & + & - & + & + & + & + & + & + & + & + & + & - & + & - & - & - & - \\
\hline UASM 4553 & + & - & + & + & + & + & + & & & & & + & & - & - & - & - \\
\hline UASM 4554 & + & - & + & + & + & + & + & & & & & + & & - & - & - & - \\
\hline UASM 4555 & + & - & + & + & + & + & + & & & & & + & & - & - & - & - \\
\hline UASM 4556 & + & - & + & + & + & + & + & & & & & + & & - & - & - & - \\
\hline UASM 4557 & + & - & + & + & + & + & + & & & & & + & & - & - & - & - \\
\hline UASM 4558 & + & - & + & + & + & + & + & & & & & + & & - & - & - & - \\
\hline UASM 4559 & + & - & + & + & + & + & + & & & & & + & & - & - & - & - \\
\hline UASM 4560 & + & - & + & + & + & + & + & & & & & + & & - & - & - & - \\
\hline UASM 4561 & + & - & + & + & + & + & + & & & & & + & & - & - & - & - \\
\hline UASM 4562 & + & - & + & + & + & + & + & & & & & + & & - & - & - & - \\
\hline UASM 4563 & + & - & + & + & + & + & + & & & & & + & & $\begin{array}{c}+ \\
\text { slow }\end{array}$ & - & - & - \\
\hline UASM 4564 & + & - & + & + & + & + & + & & & & & + & & $\begin{array}{c}+ \\
\text { slow }\end{array}$ & - & - & - \\
\hline UASM 4565 & + & - & + & + & + & + & + & & & & & + & & - & - & - & - \\
\hline UASM Q1 & + & + & + & + & + & - & - & + & + & + & + & + & + & & & - & \\
\hline $\begin{array}{l}\text { L. enzymogenes subsp. cookii } \\
\text { UASM 13B (ATCC 29488) }\end{array}$ & + & - & + & + & + & - & - & + & + & + & + & - & + & + & - & - & + \\
\hline $\begin{array}{l}\text { L. gummosus UASM } 402 \text { (ATCC } \\
\text { 29489) }\end{array}$ & + & - & $\stackrel{+}{+}$ & $\begin{array}{c}+ \\
\text { weak }\end{array}$ & + & - & - & + & + & + & + & - & + & - & - & - & - \\
\hline
\end{tabular}


INT. J. Syst. Bacteriol.

TABLE 10. Biochemical reactions of Lysobacter strains: protein hydrolysis and miscellaneous reactions ${ }^{a}$

\begin{tabular}{|c|c|c|c|c|c|c|c|c|c|c|c|c|}
\hline \multirow{3}{*}{ Strain } & & \multirow{3}{*}{ 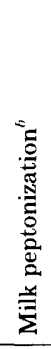 } & \multirow{3}{*}{ 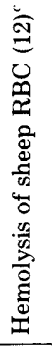 } & \multicolumn{4}{|c|}{$\begin{array}{l}\text { Growth and production of } \\
\text { ammonia in: }\end{array}$} & \multirow{3}{*}{ 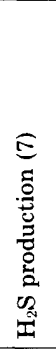 } & \multicolumn{2}{|c|}{$\begin{array}{l}\text { Growth } \\
\text { on: }\end{array}$} & \multicolumn{2}{|c|}{$\begin{array}{l}\text { Reduction of ni- } \\
\text { trates }\end{array}$} \\
\hline & & & & \multicolumn{2}{|c|}{$\begin{array}{l}\text { Penassay } \\
\text { broth } \\
\text { (11) }\end{array}$} & \multicolumn{2}{|c|}{$\begin{array}{c}\text { Salts-Casa- } \\
\text { mino Acids } \\
\text { broth } \\
(7)\end{array}$} & & \multirow{2}{*}{ 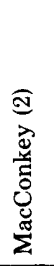 } & \multirow[b]{2}{*}{$\sum_{\substack{0 \\
0}}^{\mathbb{O}}$} & \multirow{2}{*}{ 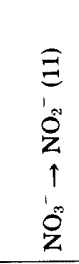 } & \multirow{2}{*}{ 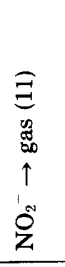 } \\
\hline & & & & 营 & $\underset{\uparrow}{\sum_{i}^{*}}$ & 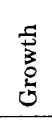 & $\underset{\uparrow}{\stackrel{5}{z}}$ & & & & & \\
\hline \multicolumn{13}{|l|}{ L. antibioticus } \\
\hline $\begin{array}{c}\text { UASM } \\
29479)\end{array}$ & (ATCC & $1^{c}$ & $\alpha$ & + & - & + & - & - & - & + & + & - \\
\hline UASM 66 & & 1 & $\beta$ & & & & & - & - & + & + & - \\
\hline $\begin{array}{l}\text { UASM L17 } \\
29480)\end{array}$ & (ATCC & 1 & $\beta$ & & & & & - & - & + & - & - \\
\hline UASM Q9 & & 1 & $\beta$ & & & & & - & + & + & + & - \\
\hline UASM Q15 & & 1 & $\beta$ & & & & & - & - & + & - & - \\
\hline $\begin{array}{l}\text { UASM } 4045 \\
29481)\end{array}$ & (ATCC & 1 & $\beta$ & & & & & - & - & + & - & - \\
\hline UASM 4169 & & 1 & $\beta$ & & & & & - & - & + & - & - \\
\hline UASM 4551 & & 1 & $\alpha$ & & & & & - & - & + & - & - \\
\hline UASM 4572 & & 1 & $\alpha$ & & & & & - & - & + & - & - \\
\hline UASM 4574 & & 1 & $\alpha$ & & & & & - & - & + & - & - \\
\hline UASM 4578 & & 1 & $\alpha$ & & & & & - & - & + & - & - \\
\hline UASM 4593 & & 1 & $\alpha$ & & & & & - & - & + & - & - \\
\hline UASM 4598 & & 1 & $\alpha$ & & & & & - & - & + & - & - \\
\hline UASM $8 \mathrm{I}$ & & 1 & $\beta$ & & & & & \pm & + & + & + & + \\
\hline UASM 10I & & 1 & $\beta$ & & & & & - & - & + & - & - \\
\hline UASM 12I & & 1 & $\beta$ & & & & & - & - & + & - & - \\
\hline \multicolumn{13}{|l|}{ L. brunescens } \\
\hline $\begin{array}{c}\text { UASM D } \\
29482)\end{array}$ & (ATCC & 1 & $\gamma$ & + & - & + & - & + & - & - & - & - \\
\hline $\begin{array}{c}\text { UASM } \\
29483)\end{array}$ & (ATCC & 1 & $\gamma$ & + & - & + & - & - & - & - & - & - \\
\hline $\begin{array}{c}\text { UASM } \\
29484)\end{array}$ & (ATCC & 1 & - & + & - & + & - & + & - & - & - & - \\
\hline UASM 4541 & & 1 & $\gamma$ & + & - & + & - & + & - & - & - & - \\
\hline UASM CB1 & & 1 & $\gamma$ & & & & & + & - & \pm & - & - \\
\hline UASM CB2 & & 1 & $\gamma$ & & & & & + & - & - & - & - \\
\hline UASM CB4 & & 1 & $\gamma$ & & & & & + & - & - & - & - \\
\hline UASM CB5 & & 1 & $\gamma$ & & & & & + & - & - & - & - \\
\hline UASM CB6 & & 1 & $\gamma$ & & & & & + & - & - & - & - \\
\hline UASM CB7 & & 1 & $\gamma$ & & & & & + & - & - & - & - \\
\hline \multicolumn{13}{|l|}{ L. enzymogenes } \\
\hline $\begin{array}{l}\text { UASM } 495 \\
29487)\end{array}$ & (ATCC & 1 & $\beta$ & + & + & + & + & + & + & + & - & - \\
\hline $\begin{array}{l}\text { UASM AL-1 } \\
\text { 27796) }\end{array}$ & (ATCC & 2 & $\beta$ & + & - & + & + & - & + & + & - & - \\
\hline ATCC 21123 & & 1 & $\beta$ & + & + & + & + & + & + & + & - & - \\
\hline $\begin{array}{c}\text { UASM } 18 \mathrm{~L} \\
29485 / 6)\end{array}$ & (ATCC & 1 & $\beta$ & + & + & + & + & - & + & + & - & - \\
\hline UASM 4553 & & 1 & $\beta$ & + & + & + & + & - & & & - & - \\
\hline UASM 4554 & & 2 & $\beta$ & + & + & + & + & - & & & - & - \\
\hline UASM 4555 & & 2 & $\beta$ & + & + & + & + & - & & & - & - \\
\hline UASM 4556 & & 2 & $\beta$ & + & + & + & + & - & & & - & - \\
\hline UASM 4557 & & 2 & $\beta$ & + & + & + & + & - & & & - & - \\
\hline UASM 4558 & & 3 & $\beta$ & + & + & + & + & - & & & - & - \\
\hline UASM 4559 & & 2 & $\beta$ & + & + & + & + & - & & & - & - \\
\hline UASM 4560 & & 1 & $\beta$ & + & + & + & + & - & & & - & - \\
\hline UASM 4561 & & 2 & $\beta$ & + & + & + & + & - & & & - & - \\
\hline UASM 4562 & & 2 & $\beta$ & + & + & + & + & - & & & - & - \\
\hline
\end{tabular}




\begin{tabular}{|c|c|c|c|c|c|c|c|c|c|c|c|}
\hline \multirow{3}{*}{ Strain } & \multirow{3}{*}{ 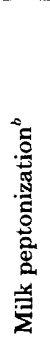 } & \multirow{3}{*}{ 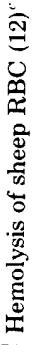 } & \multicolumn{4}{|c|}{$\begin{array}{l}\text { Growth and production of } \\
\text { ammonia in: }\end{array}$} & \multirow{3}{*}{ 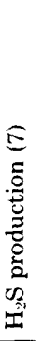 } & \multicolumn{2}{|c|}{$\begin{array}{l}\text { Growth } \\
\text { on: }\end{array}$} & \multicolumn{2}{|c|}{$\begin{array}{l}\text { Reduction of ni- } \\
\text { trates }\end{array}$} \\
\hline & & & \multicolumn{2}{|c|}{$\begin{array}{l}\text { Penassay } \\
\text { broth } \\
\text { (11) }\end{array}$} & \multicolumn{2}{|c|}{$\begin{array}{l}\text { Salts-Casa- } \\
\text { mino Acids } \\
\text { broth } \\
\text { (7) }\end{array}$} & & \multirow{2}{*}{ 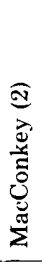 } & \multirow[b]{2}{*}{ 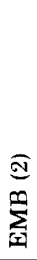 } & \multirow{2}{*}{$\begin{array}{l}\bar{\Xi} \\
\vdots \\
0 \\
z \\
1 \\
\vdots \\
\vdots \\
z\end{array}$} & \multirow{2}{*}{ 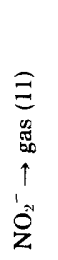 } \\
\hline & & & $\sum_{0}^{\frac{1}{2}}$ & $\overrightarrow{\bar{z}}$ & 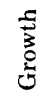 & $\stackrel{\vec{z}}{\bar{z}}$ & & & & & \\
\hline UASM 4563 & 1 & $\beta$ & + & + & + & + & - & & & - & - \\
\hline UASM 4564 & 2 & $\beta$ & + & + & + & + & - & & & - & - \\
\hline UASM 4565 & 1 & $\beta$ & + & + & + & + & - & & & - & - \\
\hline UASM Q1 & 1 & $\gamma$ & & & & & + & + & + & - & - \\
\hline $\begin{array}{l}\text { L. enzymogenes subsp. } \\
\text { cookii UASM 13B } \\
\text { (ATCC 29488) }\end{array}$ & 2 & $\alpha$ & + & + & + & + & - & - & + & - & - \\
\hline $\begin{array}{l}\text { L. gummosus UASM } 402 \\
\text { (ATCC 29489) }\end{array}$ & 1 & $\alpha$ & + & + & + & - & - & - & + & - & - \\
\hline
\end{tabular}

${ }^{a}$ Symbols. Blank, not done. Hemolysis: RBC, erythrocytes; $\gamma$, growth but no hemolysis; -, no growth; $\beta$, true hemolysis; $\alpha$, partial hemolysis. MacConkey: + , growth as small, cream-colored colonies; -, no growth. EMB: + , growth as pink colonies; \pm , small, colorless colonies; - , no growth. Reduction of nitrates: $\left(\mathrm{NO}_{3}{ }^{-} \rightarrow \mathrm{NO}_{2}{ }^{-}\right.$ column) + , no $\mathrm{NO}_{3}{ }^{-}$, no $\mathrm{NH}_{3}$, neutral reaction, $\mathrm{NO}_{2}{ }^{-}$present; - , $\mathrm{NO}_{3}{ }^{-}$present; $\left(\mathrm{NO}_{2}{ }^{-} \rightarrow\right.$ gas column): + , no $\mathrm{NO}_{2}{ }^{-}$, no $\mathrm{NO}_{3}{ }^{-}$, no $\mathrm{NH}_{3}$, neutral reaction, may have bubbles;,$- \mathrm{NO}_{2}{ }^{-}$present.

${ }^{b}$ Number of days for complete clearing.

${ }^{c}$ Numbers in parentheses are days of incubation.

TABLE 11. DNA base ratios of selected Lysobacter strains

\begin{tabular}{ll}
\hline \multicolumn{1}{c}{ Strain } & mol\% G+C \\
\hline L. antibioticus & \\
UASM 3C (= ATCC 29479) & $62^{a}, 69.2$ \\
UASM L17 (= ATCC 29480) & 68.6 \\
UASM 4045 (= ATCC 29481) & 66.2 \\
L. brunescens & \\
UASM 2 (= ATCC 29483) & $66.8,67.9$ \\
UASM D (= ATCC 29482) & $67.6,67.8$ \\
L. enzymogenes & $69.0,69.0$ \\
UASM 495 (= ATCC 29487) & 69.2 \\
UASM AL-1 (= ATCC 27796) & 70.1 \\
ATCC 21123 & 65.4 \\
L. enzymogenes subsp. cookii UASM & \\
13B (= ATCC 29488) & 65.7 \\
L. gummosus UASM 402 (= ATCC & \\
29489) &
\end{tabular}

${ }^{a}$ Datum from M. Mandel, 1961, personal communication to F. D. Cook. All other determinations were made in this laboratory.

No growth on MacConkey agar.

Habitat: Soil.

The $\mathrm{G}+\mathrm{C}$ content of the DNA of the one strain so far assigned to this subspecies is 65.4 $\operatorname{mol} \%\left(T_{m}\right)$.

Type strain: UASM 13B (= ATCC 29488).

2. Lysobacter antibioticus sp. nov. (an.ti.bi.o'ti.cus. Gr. pref. anti against; Gr.n. bius life; M.L. adj. antibioticus against life, antibiotic).

Flexible rods 0.4 by 4 to $40 \mu \mathrm{m}$ (Fig. 4).

On CCA, 5-day-old colonies are pinkish brown; circular to irregular; with a smooth surface; entire, undulate, erose, or filamentous edge; effuse, flat, raised, or convex elevation; translucent or opaque; and some or much, brown, water-soluble pigment is produced.

On SAA, 5-day-old colonies are pinkish brown; more or less circular; with a smooth surface; edge may be entire, erose, or filamentous; elevation may be effuse, flat, raised, or convex; translucent or opaque; some or much, brown, water-soluble pigment is produced.

On PCA, 5-day-old colonies are orange brown; more or less circular; with a smooth surface; edge entire, undulate, or erose; elevation raised or convex; mostly opaque; much, brown, watersoluble pigment is produced.

Older cultures on most media produce copious, brown, water-soluble pigment, and deep red crystals of the antibiotic myxin may be observed within the highly mucoid colonies.

Growth of 15 of 16 strains was reduced by $1 \%$ $\mathrm{NaCl}$ and inhibited by $3 \% \mathrm{NaCl}$; preferred atmosphere, air or $10 \% \mathrm{O}_{2}$; temperature range for growth, 2 to $40^{\circ} \mathrm{C}$; temperature for optimum growth, 25 to $33^{\circ} \mathrm{C}$.

Only one strain uses urea as $\mathrm{N}$ source. 
TABLE 12. Differential characteristics of species of the genus Lysobacter

\begin{tabular}{|c|c|c|c|c|}
\hline Characteristic & $\begin{array}{l}\text { L. antibioticus } \\
\qquad N=16^{\circ}\end{array}$ & $\begin{array}{l}\text { L. brunescens } \\
\quad N=10\end{array}$ & $\begin{array}{c}\text { L. enzymogenes } \\
N=19\end{array}$ & $\begin{array}{l}\text { L. gummosus } \\
\qquad N=1\end{array}$ \\
\hline \multicolumn{5}{|l|}{$\overline{\text { Colonies }}$} \\
\hline Type of growth & Sloppy, mucoid & Spreading, thin & Sloppy, mucoid & Pulvinate, gummy \\
\hline Smooth surface & + & - & + & + \\
\hline Opaque & + & - & + & + \\
\hline Color & $\begin{array}{l}\text { Pink to brown- } \\
\text { ish pink }\end{array}$ & Yellow to chocolate & $\begin{array}{c}\text { Cream to creamy } \\
\text { brown }\end{array}$ & Pale yellowish-gray \\
\hline Water-soluble pigment & + & + & + & - \\
\hline Broth culture viscous & + & - & + & ++++ \\
\hline Hydrolysis of CMC & + & - & + & + \\
\hline Hydrolysis of alginate & $-4 b$ & - & $t^{1}$ & - \\
\hline Hydrolysis of pectate & - & $t^{1}$ & + & + \\
\hline Hydrolysis of starch & - & + & $-{ }^{2}$ & - \\
\hline Acid from alcohols & -1 & - & $+^{4}$ & - \\
\hline Citrate as sole $\mathrm{C}$ source & + & - & + & + \\
\hline Urea as $\mathrm{N}$ source & -1 & - & $-{ }^{3}$ & + \\
\hline Growth on MacConkey & $-{ }^{2}$ & - & + & - \\
\hline Growth on EMB & + & - & + & + \\
\hline Hemolysis & $\alpha$ or $\beta$ & $\gamma$ & $\beta^{2}$ & $\alpha$ \\
\hline $\mathrm{H}_{2} \mathrm{~S}$ produced & - & $t^{1}$ & - & - \\
\hline Actinomycin D & Resistant & Susceptible & $\begin{array}{l}\text { Resistant or inter- } \\
\text { mediate }\end{array}$ & Intermediate \\
\hline Penicillin G & Resistant & $\begin{array}{l}\text { Susceptible or in- } \\
\text { termediate }\end{array}$ & Resistant & Resistant \\
\hline
\end{tabular}

${ }^{a} \mathrm{~N}$, Number of strains examined.

${ }^{b}$ Superscripts are numbers of strains giving opposite or different result.

Growth is not reduced by $0.01 \%$ SLS, but 15 of 16 strains are inhibited by $0.1 \%$ SLS; resistant to $30 \mu \mathrm{g}$ of chloramphenicol, $10 \mathrm{U}$ of penicillin, and to actinomycin D; and susceptible to $300 \mathrm{U}$ of polymyxin B; 13 of 16 strains are resistant to $10 \mu \mathrm{g}$ of streptomycin.

Eleven of 16 strains lyse one or more grampositive bacteria; only one strain lyses a gramnegative bacterium and an actinomycete; all strains lyse one of the three filamentous fungi tested, and all lyse a green alga; 8 of 16 strains lyse a yeast.

Attack on glucose is oxidative, and 11 of the 16 strains also show fermentation. Acid is produced from glucose and cellobiose; 2 of 16 strains produce acid from lactose; 1 of 16 strains produces acid from sucrose, glycerol, and mannitol.

Lipase activity is shown by 12 of 16 strains on Tween 20 , and there is a variable amount of activity from all strains on Tweens, 40,60, and 80.

Hydrolyzes CMC but not pectate or starch. Four of 16 strains hydrolyze alginate.

Liquefies gelatin; peptonizes milk in $24 \mathrm{~h}$; grows and produces $\mathrm{NH}_{3}$ on casein and Casitone broths; 1 strain of 16 grows but does not produce $\mathrm{NH}_{3}$ in Penassay and Casamino Acids broths; grows well on $0.2 \%$ tryptone agar; 7 of 16 strains are alpha-hemolytic, and 9 of 16 are beta-hemolytic.

$\mathrm{H}_{2} \mathrm{~S}$ is not produced; 2 of 16 strains show growth (with colorless colonies) on MacConkey agar; pink colonies produced on EMB; citrate test is positive.

Four of 16 strains reduce $\mathrm{NO}_{3}{ }^{-}$to $\mathrm{NO}_{2}^{-}$, and one of these strains further denitrifies $\mathrm{NO}_{2}^{-}$to a gas.

\section{Habitat: Soil.}

The $\mathrm{G}+\mathrm{C}$ content of the DNA ranges from 66.2 to $69.2 \mathrm{~mol} \%$; that of the type strain is 69.2 $\mathrm{mol} \%\left(T_{m}\right)$.

Type strain: UASM 3C (= ATCC 29479).

3. Lysobacter gummosus sp. nov. (gum.mo'sus. L. adj. gummosus slime (gum)producing).

Short rods, 0.4 by $2.0 \mu \mathrm{m}$, which glide in a series of short jerks; the cells are too short to flex (Fig. 5).

On CCA, 5-day-old colonies are pale yellowish-gray and circular with a smooth surface and entire edge; pulvinate; translucent; no water-soluble pigment is produced; gummy.

On SAA, 5-day-old colonies are pale yellowish-gray and circular with a smooth surface and entire edge; pulvinate; opaque; no water-soluble pigment is produced; very gummy.

On PCA, 5-day-old colonies are yellow-gray and circular with a smooth surface and entire edge; pulvinate; opaque; no water-soluble pigment is produced; very gummy.

Older cultures are intensely gummy and do not produce a water-soluble pigment. In very old cultures, the viscosity of the colony may de- 


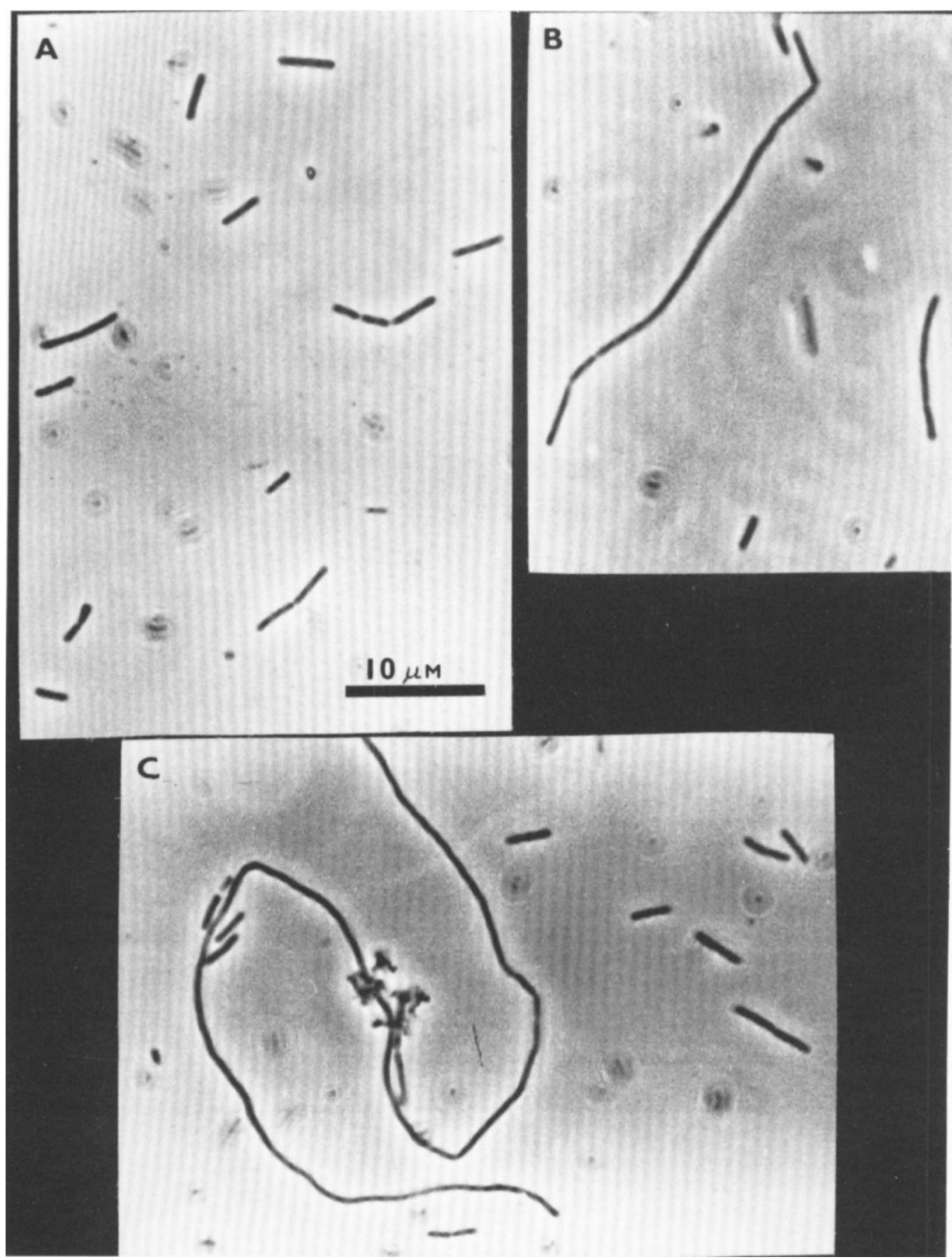

FIG. 4. Cells of Lysobacter antibioticus from skim acetate broth cultures. (A) UASM 3C (= ATCC 29479), $66 \mathrm{~h}$; (B) UASM 4593, $32 \mathrm{~h}$; (C) UASM 4578, $72 \mathrm{~h}$. All micrographs are at the same magnification.

crease dramatically, and viable cells can still be recovered from this thin slime.

Growth is reduced by $2 \% \mathrm{NaCl}$ and inhibited by $3 \% \mathrm{NaCl}$; the preferred atmosphere is air; the temperature range for growth is 10 to $40^{\circ} \mathrm{C}$; optimum growth occurs at $20^{\circ} \mathrm{C}$; the $\mathrm{pH}$ range for growth is 6 to $>10$.

Urea is used as $\mathbf{N}$ source. 


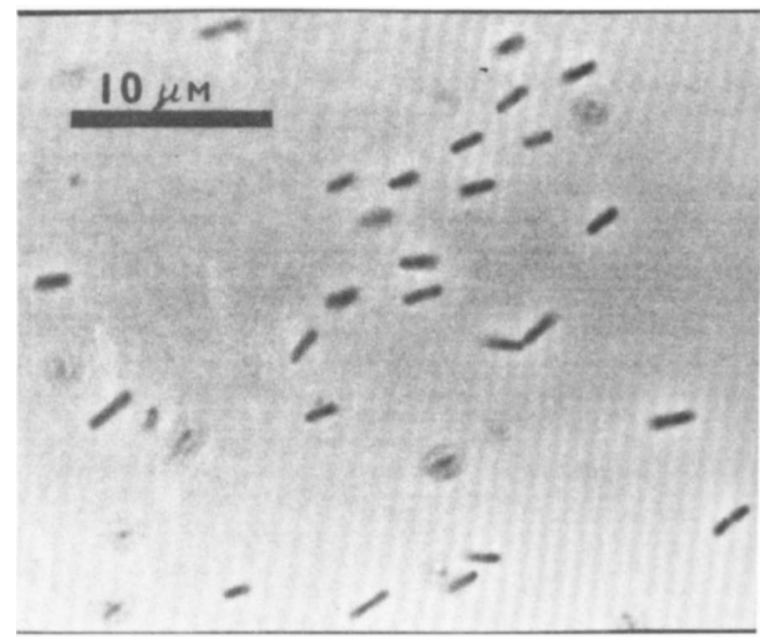

FIG. 5. Cells of Lysobacter gummosus from skim acetate broth culture, UASM 402 (= ATCC 29489), $44 \mathrm{~h}$.

Growth is not reduced by $0.01 \%$ SLS and is not inhibited by $0.1 \%$ SLS. Resistant to $30 \mu \mathrm{g}$ of chloramphenicol, $10 \mu \mathrm{g}$ of streptomycin, and 10 $\mathrm{U}$ of penicillin; susceptible to $300 \mathrm{U}$ of polymyxin $\mathrm{B}$; intermediately susceptible to actinomycin D.

Lyses gram-positive (including actinomycetes) but not gram-negative bacteria, filamentous fungi, a yeast, and an alga.

Attacks glucose oxidatively. Acid is produced from glucose, cellobiose, sucrose, and lactose, but not from glycerol or mannitol.

Shows lipase activity on Tweens 20, 40, 60, and 80 .

Hydrolyzes pectate and CMC but not alginate or starch.

Liquefies gelatin; peptonizes milk in $24 \mathrm{~h}$; grows and produces $\mathrm{NH}_{3}$ on casein, Penassay, and Casitone broths; grows but does not produce $\mathrm{NH}_{3}$ on Casamino Acids broth; grows well on $0.2 \%$ tryptone agar; alpha-hemolytic.

$\mathrm{H}_{2} \mathrm{~S}$ is not produced; the oxidase test is equivocal; no growth is produced on MacConkey agar; pink colonies occur on EMB; the citrate test is positive.

Does not reduce $\mathrm{NO}_{3}{ }^{-}$or $\mathrm{NO}_{2}{ }^{-}$.

Habitat: Soil.

The $\mathrm{G}+\mathrm{C}$ content of the DNA of the one strain so far assigned to this species is $65.7 \mathrm{~mol} \%$ $\left(T_{m}\right)$.

Type strain: UASM 402 (= ATCC 29489).

4. Lysobacter brunescens sp. nov. (bru.nes'cens. L.v. brunesco to become dark brown; L. part. adj. brunescens becoming dark brown). $6)$.
On CCA, 5-day-old colonies are brownish-yellow and irregular with a rough surface; the edge may be undulate, lobate, erose, or filamentous; the elevation is effuse; the center is convex or umbonate; transparent; variable amounts of a brown, water-soluble pigment are produced.

On SAA, 5-day-old colonies are yellow-brown and circular to irregular; rough or smooth surface; edge may be entire, undulate, lobate, erose, or filamentous; the elevation is effuse, sometimes raised; the centers are often raised, convex, or umbonate; transparent or translucent; variable amounts of a brown, water-soluble pigment are produced.

On PCA, 5-day-old colonies are deep yellowbrown and circular to irregular; smooth or rough surface; the edge may be entire, undulate, erose, or filamentous; the elevation is effuse, raised, or convex; the center may sometimes be umbonate; translucent; typically, a dark brown, water-soluble pigment is copiously produced.

Older cultures on all media produce copious, dark-brown, water-soluble pigment.

Growth of 9 or 10 strains is reduced by $1 \%$ $\mathrm{NaCl}$ and inhibited by $2 \% \mathrm{NaCl}$; the preferred atmosphere is air or $10 \% \mathrm{O}_{2}$; the temperature range for growth is 4 to $50^{\circ} \mathrm{C}$; for optimum growth, it is 30 to $40^{\circ} \mathrm{C}$.

Eight of 10 strains utilize asparaginate as $\mathrm{N}$ source. Urea is not used as $\mathrm{N}$ source.

Growth of 5 of 10 strains is not reduced by $0.01 \%$ SLS; all strains are inhibited by $0.1 \%$ SLS. Susceptible to $30 \mu \mathrm{g}$ of chloramphenicol, $300 \mathrm{U}$ of polymyxin $B$, and to actinomycin $D ; 8$ of 10 strains are susceptible to $10 \mathrm{U}$ of penicillin G; 6 of 10 strains are susceptible to $10 \mu \mathrm{g}$ of streptomycin. 


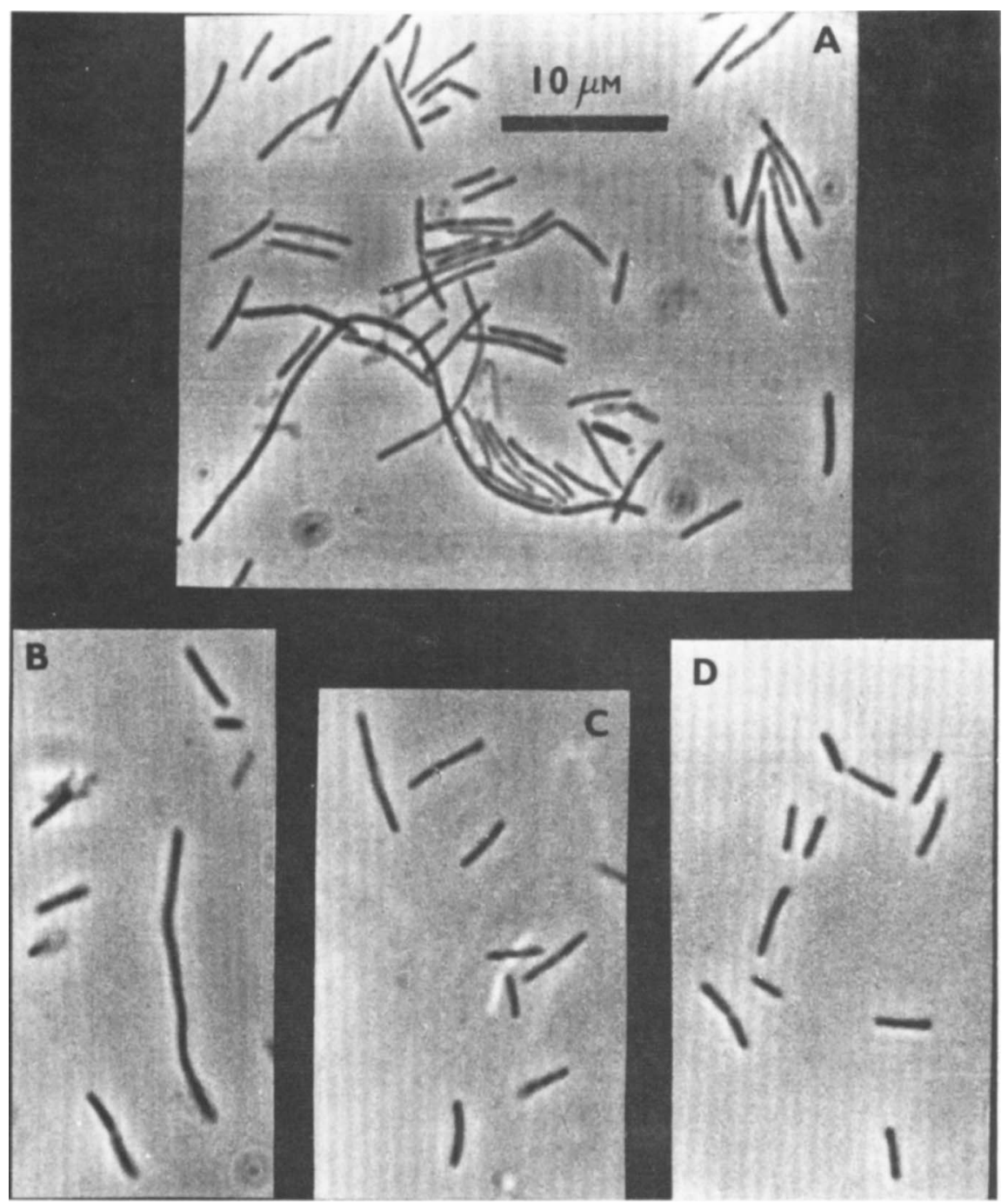

Fig. 6. Cells of Lysobacter brunescens from skim acetate broth cultures. (A) UASM 2 (= ATCC 29483), 60 h; (B) UASM D (=ATCC 29482), $60 \mathrm{~h}$; (C) UASM 4541, $44 \mathrm{~h}$; (D) UASM CB5, 30 h. All micrographs are at the same magnification.

Ninety percent or more of the isolates lyse gram-negative bacteria, a yeast, and an alga; 40 to $50 \%$ of the isolates lyse gram-positive bacteria (including actinomycetes) and filamentous fungi.

Attacks glucose oxidatively; 3 of 10 strains also attack glucose fermentatively. Nine of 10 strains produce acid from glucose. No acid is produced from cellobiose, sucrose, lactose, glycerol, or mannitol.

Lipase activity: There is no activity on Tween 20. Two of 4 strains are positive on Tween $40 ; 4$ of 4 are positive on Tween 60 ; and 2 of 10 are positive on Tween 80 .
Hydrolyzes starch; 9 of 10 strains hydrolyze pectate. There is no action on alginate or CMC.

Liquefies gelatin; peptonizes milk in $24 \mathrm{~h}$; grows and produces $\mathrm{NH}_{3}$ in casein and Casitone broths; four of four strains grow but do not produce $\mathrm{NH}_{3}$ in Penassay and Casamino Acids broths; grows well on $0.2 \%$ tryptone agar; nonhemolytic.

Nine of 10 strains produce $\mathrm{H}_{2} \mathrm{~S}$; no growth occurs on MacConkey agar; only 1 of 10 strains grows on EMB, producing small, colorless colonies; the citrate test is negative.

Does not reduce $\mathrm{NO}_{3}^{-}$or $\mathrm{NO}_{2}^{-}$.

Habitat: Fresh water. 
TABLE 13. Characteristics useful in differentiating the genera Cytophaga and Lysobacter and the order Myxobacterales ${ }^{a}$

\begin{tabular}{|c|c|c|c|}
\hline Differential character & Cytophaga & Lysobacter & Myxobacterales \\
\hline $\begin{array}{l}\text { DNA base ratio }(\mathrm{mol} \% \\
\mathrm{G}+\mathrm{C})\end{array}$ & $29-42$ & $65-70$ & $67-71$ \\
\hline Fruiting bodies & - & - & + \\
\hline Colony color & Yellow, orange, or red & $\begin{array}{l}\text { White, cream, yellow, } \\
\text { brown, pink, or red }\end{array}$ & $\begin{array}{l}\text { Gray, yellow, orange, } \\
\text { brown, pink, red, pur- } \\
\text { ple, or nearly black }\end{array}$ \\
\hline $\begin{array}{l}\text { Brown, water-soluble pig- } \\
\text { ment production }\end{array}$ & In one pink sp. only & $\begin{array}{l}\text { In all except one whitish- } \\
\text { yellow sp. }\end{array}$ & \pm \\
\hline $\begin{array}{l}\text { Optical properties of col- } \\
\text { ony }\end{array}$ & Mainly transparent & $\begin{array}{l}\text { Translucent or opaque ex- } \\
\text { cept for one yellow- } \\
\text { brown sp. }\end{array}$ & $\begin{array}{l}\text { Transparent, translu- } \\
\text { cent, or opaque }\end{array}$ \\
\hline Degradation of filter paper & \pm & - & \pm \\
\hline Degradation of agar & \pm & - & \pm \\
\hline Degradation of chitin & One yellow sp. only & + & \pm \\
\hline Antimicrobial lytic action & A few strains & All species & Most species \\
\hline Actinomycin D & Susceptible & $\begin{array}{l}\text { Three of the four spp. are } \\
\text { resistant }\end{array}$ & Susceptible \\
\hline
\end{tabular}

"Symbols: +, all species positive; - , all species negative; \pm , some species or some strains positive.

The $\mathrm{G}+\mathrm{C}$ content of the DNA ranges from 66.8 to $67.9 \mathrm{~mol} \%$; that of the type strain ranges from 67.6 to $67.8 \mathrm{~mol} \%\left(T_{m}\right)$.

Type strain: UASM D (= ATCC 29482).

Assignment of an unidentified, gliding, polysaccharolytic isolate to the genus Cytophaga, to the genus Lysobacter, or to the order Myxobacterales can be achieved on the basis of two fundamental characteristics: DNA base ratio and fruiting-body formation. Since these are not usually the first items of information gleaned about an unidentified isolate, other characteristics useful in differentiating between the abovementioned taxa are listed in Table 13. This table relies heavily on colony characteristics because of the paucity of biochemical data on Cytophaga and Myxobacterales.

The degradation of polysaccharides is important in all three groups but is of only minor help in differentiating between these groups. Some species or strains of Cytophaga, of Lysobacter, and of myxobacteria can hydrolyze CMC, starch, and/or chitin. Alginate and pectate are degraded by some cytophagas and by some lysobacters but are not known to be degraded by myxobacters (only three strains have been tested [P. Christensen, unpublished results]). However, the polysaccharase potential is of value in the identification of individual species within the genera Cytophaga and Lysobacter and within the order Myxobacterales.

We have recently found that the colonial morphologies of some strains of three Lysobacter species appear to change slightly after the cells have been freeze-dried. In addition, it has come to our attention that strains of $L$. enzymogenes do not exhibit as strong a microbial lytic action and do not maintain as high a level of certain proteolytic enzymes after they have been maintained in the laboratory on skim milk media for some time.

As a result of these observations, the following recommendations are made: (i) those workers who need Lysobacter cultures with antimicrobial lytic action and who find that cultures received from the American Type Culture Collection are unsuitable in this regard should isolate their own strains directly from soil by the simple method outlined in Materials and Methods (this is by far the best way to insure high activity); and (ii) workers should maintain strains of $L y$ sobacter on CCA (8), on which medium the organisms do not appear to lose their polysaccharolytic and proteolytic potential.

\section{ACKNOWLEDGMENTS}

We thank Dorothea Donass, Linda Webster, and Ann Webster for cheerful and efficient technical assistance and Roger Phillippe for performing the DNA base-ratio analyses. Gratitude is expressed to the National Research Council of Canada for a postdoctoral Fellowship to the senior author.

\section{REPRINT REQUESTS}

Address reprint requests to: Dr. F. D. Cook, Department of Microbiology, University of Alberta, Edmonton, Alberta, Canada T6G 2E3.

\section{LITERATURE CITED}

1. Allen, L. C., and D. R. Whitaker. 1972. The $\beta$-lytic protease of myxobacter 495 : aspects of its specificity. Proc. Can. Fed. Biol. Soc. 15:\#31.

2. American Type Culture Collection. 1974. Catalogue of strains (bacteria), 11th ed. American Type Culture Collection, Rockville, Md.

3. Bailey, W. R., and E. G. Scott. 1970. Diagnostic microbiology, 3rd ed. Mosby, St. Louis, Mo.

4. Behki, R. M., and S. M. Lesley. 1972. Deoxyribonucleic 
acid degradation and the lethal effect by myxin in Escherichia coli. J. Bacteriol. 109:250-261.

5. Buchanan, R. E., and N. E. Gibbons (ed.). 1974. Bergey's manual of determinative bacteriology. Williams and Wilkins Co., Baltimore.

6. Christensen, P. J. 1974. A new approach to the description of colony colour of cytophagas and their allies. Can J. Microbiol. 20:937-942.

7. Christensen, P. J. 1977. Synonymy of Flavobacterium pectinovorum Dorey with Cytophaga johnsonae Stanier. Int. J. Syst. Bacteriol. 27:122-132.

8. Christensen, P. J., and F. D. Cook. 1972. The isolation and enumeration of cytophagas. Can. J. Microbiol. 18:1933-1940.

9. Daft, M. J., and W. D. P. Stewart. 1971. Bacterial pathogens of fresh-water blue-green algae. New Phytol. 70:819-829.

10. Damoglou, A. P., L. C. Allen, C. Roy, and D. R. Whitaker. 1972. The $\beta$-lytic protease of myxobacter 495: aspects of its structure. Proc. Can. Fed. Biol. Soc. 15:\#27.

11. Dworkin, M., and S. M. Gibson. 1964. A system for studying microbial morphogenesis: rapid formation of microcysts in Myxococcus xanthus. Science 146:243-244.

12. Ensign, J. C., and R. S. Wolfe. 1965. Lysis of bacterial cell walls by an enzyme isolated from a myxobacter. $J$ Bacteriol. 90:395-402.

13. Ensign, J. C., and R. S. Wolfe. 1966. Characterization of a small proteolytic enzyme which lyses bacterial cel walls. J. Bacteriol. 91:524-534.

14. Gillespie, D. C., and F. D. Cook. 1965. Extracellular enzymes from strains of Sorangium. Can. J. Microbiol. 11:109-118

15. Hedges, A., and R. S. Wolfe. 1974. Extracellular enzyme from myxobacter AL-1 that exhibits both B-1, 4-glucanase and chitosanase activities. J. Bacteriol. 120:844-853.

16. Jackson, R. L., and G. R. Matsueda. 1970. Myxobacter AL-1 protease. Methods Enzymol. 19:591-599.

17. Jackson, R. L., and R. S. Wolfe. 1968. Composition, properties and substrate specificities of Myxobacter AL1 protease. J. Biol. Chem. 243:879-888.

18. Katznelson, H., D. C. Gillespie, and F. D. Cook. 1964 Studies on the relationships between nematodes and other soil micro-organisms. III. Lytic action of soil myxobacters on certain species of nematodes. Can. J. Microbiol. 10:699-704.

19. Lesley, S. M., and R. M. Behki. 1967. Mode of action of myxin on E. coli. J. Bacteriol. 94:1837-1845.

20. Lesley, S. M., and R. M. Behki. 1971. Recovery of metabolic activity in E. coli following limited exposure to myxin. Can. J. Microbiol. 17:1327-1333.

21. Lesley, S. M., R. M. Behki, and D. C. Gillespie. 1967 Production of radioactive myxin. Can. J. Microbiol. 13:1251-1257.

22. Marmur, J., and P. Doty. 1962. Determination of the base composition of DNA from its thermal denaturation temperature. J. Mol. Biol. 5:109-118.

23. Martin, S. M., and V. So. 1969. Solubilization of autoclaved feathers and wool by myxobacteria. Can. J. Microbiol. 15:1393-1397.

24. Matheson, A. T., and K. Mikulik. 1972. The influence of growth conditions and isolation procedures on the proteolytic breakdown of ribosomal proteins from Myxobacter 495. Can. J. Microbiol. 18:355-359.

25. Pate, J. L., J. L. Johnson, and E. J. Ordal. 1967. The fine structure of Chondrococcus columnaris. II. Structure and formation of rhapidosomes. J. Cell. Biol. 35: $15-35$.

26. Pate, J. L., and E. J. Ordal. 1967. The fine structure of Chondrococcus columnaris. I. Structure and formation of mesosomes. J. Cell. Biol. 35:1-14.

27. Peterson, E. A., D. C. Gillespie, and F. D. Cook. 1966. A wide-spectrum antibiotic produced by a species of Sorangium. Can. J. Microbiol. 12:221-230.

28. Peterson, E. A., H. Katznelson, and F. D. Cook. 1965. The influence of chitin and myxobacters on numbers of actinomyctes in soil. Can. J. Microbiol. 2:595-596.

29. Sendecki, W., K. Mikulik, and A. T. Matheson. 1971. Some properties of ribosomes from Myxobacter 495. Can. J. Biochem. 49:1333-1339.

30. Shilo, M. 1970. Lysis of blue-green algae by myxobacter. J. Bacteriol. 104:453-461.

31. Sierra, G. 1957. A simple method for the detection of lipolytic activity of micro-organisms and some observations on the influence of the contact between cells and fatty substances. Antonie van Leeuwenhoek J. Microbiol. Serol. 23:15-22.

32. Smit, M., and A. G. Clark. 1971. The observation of myxobacterial fruiting bodies. J. Appl. Bacteriol. 34:399-401.

33. Soriano, S. 1945. El nuevo orden Flexibacteriales y la clasificación de los órdenes de las bacterias. Rev. Argent. Agron. 12:120-140.

34. Stanier, R. Y. 1957. Order VIII. Myxobacterales Jahn 1915, p. 854-891. In R. S. Breed, E. G. D. Murray, and N. R. Smith (ed.), Bergey's manual of determinative bacteriology, 7th ed. The Williams and Wilkins Co., Baltimore.

35. Stewart, J. R., and R. M. Brown. 1969. Cytophaga that kills or lyses algae. Science 164:1523-1524.

36. Stewart, J. R., and R. M. Brown. 1971. Algicidal nonfruiting myxobacteria with high $\mathrm{G}+\mathrm{C}$ ratios. Arch. Mikrobiol. 80:176-190.

37. Tan, I., W. Hartmann, U. Guntermann, A. Hüttermann, and H. Kühlwein. 1974. Studies on the cell cycle of Myxobacter AL-1. I. Size fractionation of exponentially growing cells by zonal centrifugation. Arch. Mikrobiol. 100:389-396.

38. Whitaker, D. R. 1965. Lytic enzymes of Sorangium sp: isolation and enzymatic properties of the $\alpha$ - and $\beta$ proteases. Can. J. Biochem. 43:1935-1954.

39. Whitaker, D. R. 1967. Simplified procedures for production and isolation of the bacteriolytic proteases of Sorangium sp. Can. J. Biochem. 45:991-993.

40. Whitaker, D. R. 1970 . The $\alpha$-lytic protease of a myxobacterium. Methods Enzymol. 19:599-613.

41. Whitaker, D. R., F. D. Cook, and D. C. Gillespie. 1965 Lytic enzymes of Sorangium sp. Some aspects of enzyme production in submerged culture. Can. J. Biochem. 43:1927-1933.

42. Whitaker, D. R., C. Roy, C. S. Tsai, and L. Jurášek. 1965. Lytic enzymes of Sorangium sp. A comparison of the proteolytic properties of the $\alpha$ - and $\beta$-lytic proteases. Can. J. Biochem. 43:1961-1970. 